CHARLES RICARDO MORGAN

\title{
Estudo da estimulação elétrica nervosa transcutânea (TENS) nível sensório para efeito de analgesia em pacientes com osteoartrose de joelho
}

Dissertação apresentada à Faculdade de Medicina da Universidade de São Paulo para obtenção do título de Mestre em Ciências

Programa de: Ciências Médicas

Área de concentração: Distúrbios do crescimento celular, hemodinâmicos e da hemostasia

Orientador: Prof. Dr. Franklin Santana Santos

São Paulo

2010 
Dados Internacionais de Catalogação na Publicação (CIP)

Preparada pela Biblioteca da

Faculdade de Medicina da Universidade de São Paulo

Creprodução autorizada pelo autor

\section{Morgan, Charles Ricardo}

Estudo da estimulação elétrica nervosa transcutânea (TENS) nível sensório para efeito de analgesia em pacientes com osteoartrose de joelho / Charles Ricardo Morgan. -- São Paulo, 2010.

Dissertação(mestrado)--Faculdade de Medicina da Universidade de São Paulo. Programa de Ciências Médicas. Área de concentração: Distúrbios do Crescimento Celular, Hemodinâmicos e da Hemostasia.

Orientador: Franklin Santana Santos.

Descritores: 1.Osteoartrose 2.Joelho 3.Dor 4.Estimulação elétrica nervosa transcutânea 5.Questionário de avaliação de dor 6.Questionário de avaliação funcional

USP/FM/DBD-454/10 
"Conhecemos um homem pelo seu riso; se na primeira vez que o encontramos ele ri de maneira agradável, o íntimo é excelente." Fiodor Dostoievski 


\section{DEDICATÓRIAS}

A minha esposa Kátia, a companheira presente. Nesta fase da minha vida soube sempre estimular nos momentos mais difíceis. Reafirmo a você meu amor e união.

Aos meus filhos Catharina, Ricardo e Sophia. Vocês meus filhos são meu sorriso a cada ida e vinda. Ao ver o trabalho concluído estou feliz e desejo muita felicidade a minha família, vejo o quanto vocês são significativos para mim.

A minha mãe Ires Balen Morgan, um exemplo de esforço e dedicação à família, sempre disposta a ajudar em qualquer momento e circunstância. Essa dissertação é mais uma afirmação do amor materno.

Ao meu pai Nelson José Morgan, que na sua simplicidade procurou ensinar os valores morais e de caráter que um homem digno deve ter. Um homem muito atencioso com a família.

Também a minhas irmãs, que este esforço sirva de exemplo em suas carreiras, lutem por suas aspirações. 


\section{AGRADECIMENTOS}

Agradeço ao Prof. Dr. Franklin Santana Santos. Sua orientação sempre atenciosa com as questões referentes ao projeto desta dissertação, com carinho e dedicação necessários, refletindo o conhecimento que possui. É motivo de orgulho e agradecimento pela oportunidade.

Agradeço ao Dr. José Ricardo Pécora, o qual foi importante para o desenvolvimento da pesquisa junto ao Instituto de Ortopedia e Traumatologia da Faculdade de Medicina da Universidade de São Paulo.

Às funcionárias da disciplina de emergências Clínicas: Angélica, Rose e Eliane pela paciência, atenção e compreensão neste período.

Ao serviço de Fisioterapia do Instituto de Ortopedia e Traumatologia da FMUSP

À bibliotecária Valéria Vilhena, sempre atenciosa e disposta a ajudar. Agradeço a toda equipe da biblioteca central da FMUSP.

Agradeço ao Dr. Jurandir Godoy Duarte pela análise estatística desta dissertação, e também pela orientação na análise dos dados.

À CAPES (Coordenação de Aperfeiçoamento de Pessoal e Nível Superior) pelo apoio financeiro, fundamental no desenvolvimento da pesquisa.

A todos os pacientes que compareceram as avaliações e ao tratamento, pela paciência e assiduidade. 


\section{Normalização adotada}

Esta dissertação está de acordo com as seguintes normas, em vigor no momento desta publicação:

Referências: adaptado de International Committee of Medical Journals Editors (Vancouver)

Universidade de São Paulo. Faculdade de Medicina. Serviço de Biblioteca e documentação. Guia de apresentação de dissertações, teses e monografias. Elaborado por Annelise Caneiro da Cunha, Maria Júlia de A. L. Freddi, Maria F. Crestana, Marinalva de Souza Aragão, Suely Campos Cardoso, Valéria Vilhena. $2^{\mathrm{a}}$ ed. São Paulo: Serviço de biblioteca e documentação; 2005.

Abreviaturas dos títulos dos periódicos de acordo com List of Journals Indexed in Index Medicus. 
Lista de Abreviaturas e siglas....................................................................viii

Lista de Tabelas.................................................................................

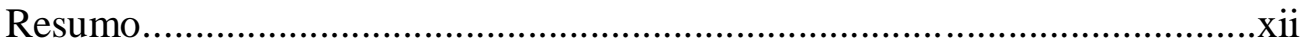

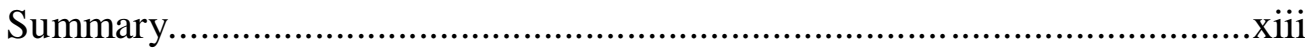

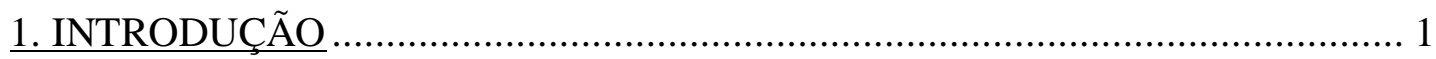

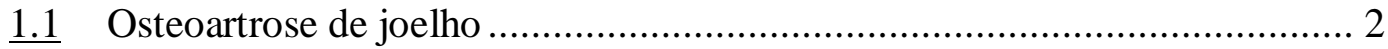

1.2 A classificação da artrose .................................................................. 4

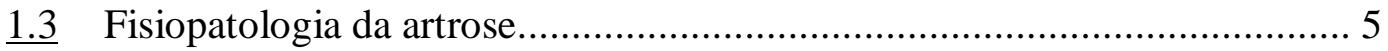

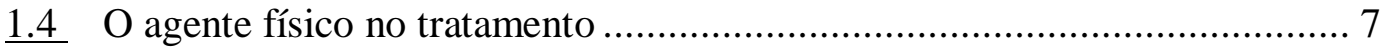

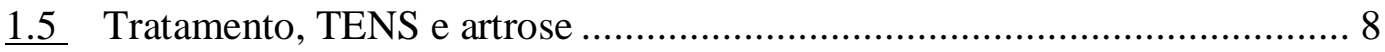

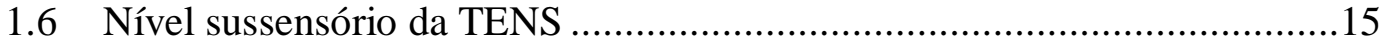

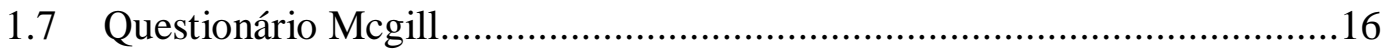

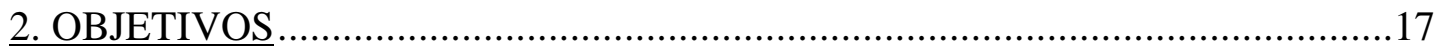

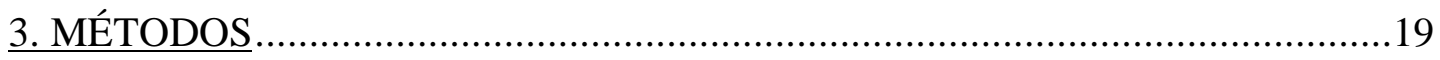

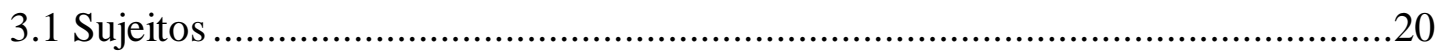

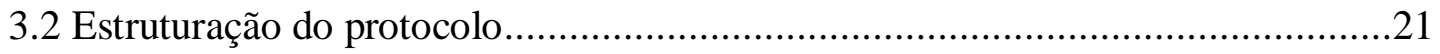

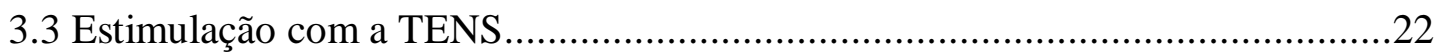

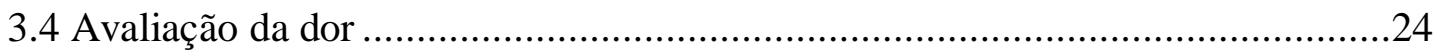

3.5 Questionário de avaliação funciona ......................................................... 251

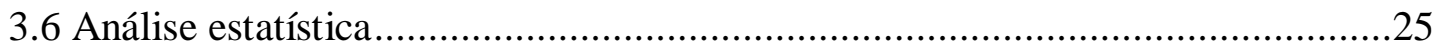

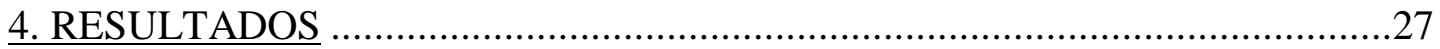

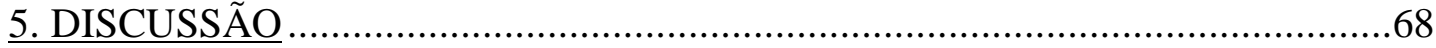

CONCLUSÕES

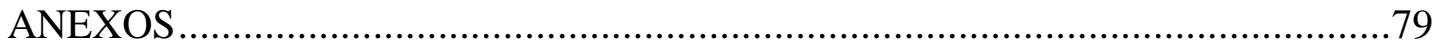

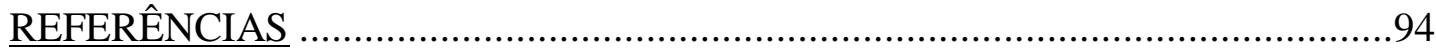




\section{LISTA DE ABREVIATURAS}

$\mathrm{Hz}$

AVD

SG

TENS

E35

M-MI-27

BP9

VB34

$\mu \mathrm{A}$

$\mathrm{mA}$

ms

IASP

T

$\mathrm{OA}$

MPQ

WOMAC

OAJ
Hertz

Atividades da vida diária

Substância Gelatinosa

Estimulação elétrica nervosa transcutânea

Ponto do meridiano da acupuntura do estômago

Ponto de acupuntura extra do membro inferior

Ponto do meridiano da acupuntura do baço pâncreas

Ponto do meridiano da acupuntura vesícula biliar

microampère

Miliampere

milissegundo

International Association for the Study of Pain

Tempo

Osteoartrose

O questionário de dor McGill

The Western Ontario and McMaster Universities Index

Osteoartrose de joelho 


\section{LISTA DE TABELAS}

Tabela 1 - como a sua dor muda com o tempo

Tabela 2 - Ao se avaliar o tipo da dor nas diferentes entrevistas

Tabela 3 - Que tipo de coisas alivia sua dor

Tabela 4 - Avaliação da inteligência do paciente para aplicação do questionário

Tabela 5 - Avaliação de quão forte é a sua dor

Tabela 6 - Dor exatamente neste momento

Tabela 7 - Palavra no pior momento

Tabela 8 - Pior dor de dente que você sentiu

Tabela 9 - Pior dor de cabeça que você sentiu

Tabela 10 - Pior dor de estômago que você sentiu

Tabela 11 - Descritores sensitivos

Tabela 12 - Descritores afetivos

Tabela 13 - Descritores avaliativos

Tabela 14 - Descritores miscelânea

Tabela 15 - Descritores quantidade total

Tabela 16 - Índice de dor sensitivo

Tabela 17 - Índice de dor afetivo

Tabela 18 - Índice de dor Avaliativo

Tabela 19 - Índice de dor miscelânea

Tabela 20 - Índice de dor total

Tabela 21 - Escala analógica visual da dor, variando de 0 a $10 \mathrm{~cm}$

Tabela 22 - Marcação em uma linha solicitando o seu nível de dor, variando de 0 a 10

Tabela 23 - Em que grau a dor em seu joelho afeta o seu nível de atividade diária 
Tabela 24 - A que grau o rangido ou crepitação do seu joelho afeta o seu nível de atividade diária

Tabela 25 - Em que grau a rigidez no seu joelho afeta o seu nível de atividade diária Tabela 26 - A que grau o aumento de volume no joelho afeta o seu nível de atividade diária Tabela 27 - Em que grau o deslizamento do joelho afeta o seu nível de atividade diária Tabela 28 - Em que grau o bloqueio do seu joelho afeta o nível de atividade diária Tabela 29 - Em que grau a fraqueza ou falta de força d seu membro inferior afeta o seu nível de atividade diária

Tabela 30 - Como seu joelho afeta sua capacidade de marcha

Tabela 31 - Por causa do seu joelho, você anda com muletas ou uma bengala

Tabela 32 - O seu joelho faz você mancar quando anda

Tabela 33 - Como o seu joelho afeta sua capacidade de subir escadas

Tabela 34 - Como o seu joelho afeta sua capacidade de descer escadas

Tabela 35 - Como o seu joelho afeta a capacidade de ficar em pé

Tabela 36 - Como o seu joelho afeta sua capacidade de se ajoelhar

Tabela 37 - Como o seu joelho afeta a capacidade de agachar-se

Tabela 38 - Como o seu joelho afeta a capacidade sentar-se com o joelho dobrado

Tabela 39 - Como o seu joelho afeta sua capacidade de levantar-se de uma cadeira

Tabela 40 - Como você classificaria o seu nível atual da função do joelho durante as suas atividades diárias usuais em uma escala de 0 a 100, com 100 sendo o seu nível de função do joelho antes da sua lesão

Tabela 41 - Como você classificaria a função global do seu joelho durante as suas atividades diárias usuais

Tabela 42 - Como resultado da lesão em seu joelho, como você classificaria o seu nível atual de atividade diária

Tabela 43 - Desde o início do tratamento do joelho, como você descreveria o seu progresso Tabela 44 - Antes da lesão de seu joelho, como você descreveria o seu nível usual de atividade 
Tabela 45 - Antes da cirurgia ou do tratamento de seu joelho, como você descreveria a sua atividade diária usual

Tabela 46 - Como você descreveria o seu nível atual de atividade diária

Tabela 47 - Para cada paciente foi feita uma avaliação antes e depois de cada uma das dez sessões de fisioterapia a que foram submetidos. Os índices variaram de 0 a 10 , com os seguintes resultados comparativos em relação a $1^{\mathrm{a}}$ sessão

Tabela 48 - Para cada paciente foi feita uma avaliação antes e depois de cada uma das dez sessões de fisioterapia a que foram submetidos. Os índices variaram de 0 a 10 , com os seguintes resultados comparativos em relação a $2^{\mathrm{a}}$ a $10^{\mathrm{a}}$ sessão 


\section{RESUMO}

Morgan CR. Estudo da estimulação elétrica nervosa transcutânea (TENS) nível sensório para efeito de analgesia em pacientes com osteoartrose de joelho [Dissertação]. São Paulo: Faculdade de Medicina, Universidade de São Paulo, 2010.

INTRODUÇÃO: A osteoartrose de joelho $(\mathrm{OAJ})$ é uma das patologias que mais afetam o aparelho locomotor e interferem de forma considerável nas atividades da vida diária, acometendo os indivíduos em faixa etária variável e em diversos graus e níveis de dor articular. As propostas terapêuticas são bastante diversificadas para a osteoartrose (OA), a terapia física, a TENS está para colaborar no tratamento dos pacientes com osteoartrose de joelho. OBJETIVOS: Devido à importância da articulação do joelho nas atividades locomotoras e sua relação com as atividades da vida diária. Os pacientes com osteoartrose de joelho sofrem não somente pelo problema localizado, existe uma alteração funcional global que pode levar a processos dolorosos em outras articulações. Para uma eficaz orientação e avaliação do paciente primeiro é necessário que este faça a descrição clara de sua dor para que o profissional perceba como que esse estímulo doloroso prejudica sua vida. O objetivo do presente estudo foi avaliar o efeito da estimulação elétrica nervosa transcutânea (sigla em inglês TENS) nível sensório para tratamento de dor em pacientes com diagnóstico de osteoartrose de joelho, utilizando escalas de avaliação de dor, escala de avaliação funcional. MÉTODOS: Foram estudados 10 pacientes com diagnóstico de osteoartrose de joelho, utilizando uma modalidade fisioterapêutica, a eletroterapia, especificamente a (TENS), com parâmetros de $80 \mathrm{~Hz}$ e $140 \mu \mathrm{s}$, com um total de 10 sessões, 30 minutos para cada sessão, o período total de tratamento compreendeu 4 semanas, nesse total de 10 sessões, cada paciente foi entrevistado com um questionário na $1^{\text {a }}$ sessão, na $5^{\text {a }}$ e na $10^{\mathrm{a}}$ sessão. Os formulários utilizados foram Questionário da Dor McGill - Melzack, escala Analógica visual da dor, escala numérica com expressão facial de sofrimento, escala de atividades da vida diária da knee Outcome Survey - RESULTADOS: O resultado com a TENS nível sensório para efeito de analgesia mostra que as diferenças foram estatisticamente significativas $(\mathrm{p}<0,05)$ para escala Analógica visual da dor e o Questionário da Dor McGill, em alguns itens da escala de atividades da vida diária da knee Outcome Survey houve significância estatística. CONCLUSÃO: Nossos resultados sugerem que a TENS nível sensório reduz a dor e melhora a funcionalidade do joelho em alguns pontos da escala de atividades da vida diária em pacientes com OAJ.

Descritores: 1. Osteoartrose 2. Joelho 3. Dor 4.Estimulação elétrica nervosa transcutânea 5.Questionário de avaliação de dor 6.Questionário de avaliação funcional. 


\section{SUMMARY}

Morgan CR. Study of transcutaneous electrical nerve stimulation (TENS) for the sensory effect of analgesia in patients with knee osteoarthritis [dissertation]. São Paulo: "Faculdade de Medicina, Universidade de São Paulo", 2010.

INTRODUCTION: Knee osteoarthritis (KOA) is one of the diseases that most affect the locomotor system and interfere significantly in activities of daily life, affecting individuals at varying ages and in different degrees and levels of joint pain. The proposals are quite diverse therapies for osteoarthritis (OA), physical therapy, TENS is to collaborate in the treatment of patients with osteoarthritis of the knee. OBJECTIVES: Because of the importance of the knee joint in locomotor activity and its relation to the activities of daily living. Patients with osteoarthritis of the knee not only suffer the problem located, there is a change in overall functional processes that can lead to pain in other joints. To provide efficient guidance and evaluation of the patient first must make this clear description of their pain for the professional to realize how painful stimulus that affect their lives. The aim of this study was to evaluate the effect of transcutaneous electrical nerve stimulation (TENS acronym in English) to the sensory processing of pain in patients with osteoarthritis of the knee, using rating scales of pain, functional scale. METHODS: We studied 10 patients with osteoarthritis of the knee, using a modality physiotherapy, electrotherapy, specifically (TENS), with parameters of $80 \mathrm{~Hz}$ and $140 \mu \mathrm{s}$, with a total of 10 sessions, 30 minutes for each session, the period Total treatment included 4 weeks in total of 10 sessions, each patient was interviewed with a questionnaire in the first session, on the 5th and 10th session. The forms used were the McGill Pain Questionnaire - Melzack, visual analogue pain scale, numerical scale with facial expression of pain, range of activities of daily living of the Knee Outcome Survey - RESULTS: The result with TENS for the effect of sensory analgesia shows that the differences were statistically significant ( $p$ $<0.05$ ) for visual analogue pain scale and McGill Pain Questionnaire, in some items of the scale of activities of daily living knee Outcome Survey of statistical significance. CONCLUSION: Our results suggest that sensory TENS reduces pain and improves knee function in some points of the scale of activities of daily living in patients with KOA.

Keywords: 1.Osteoarthritis 2.Knee 3.Pain 4.Transcutaneous electrical nerve stimulation 5.Questionnaire assessment of pain 6.functional assessment questionnaire. 
1 INTRODUÇÃO 


\subsection{Osteoartrose de joelho}

Em relação à incidência de osteoartrose de joelho nos Estados Unidos da América do Norte, mais de 10 milhões de americanos apresentam esta doença (Lawrence et al, 1998). Estudos Radiológicos demonstraram que a frequência gira em torno de $5 \%$ em indivíduos com menos de 30 anos e, atinge $70 \%$ a $80 \%$ daqueles com mais de $65 \%$. Contudo, somente $20 \%$ a $30 \%$ dos portadores de alterações radiológicos apresentam sintomas da doença. Na articulação do joelho, evidenciou-se, que 52\% da população adulta apresentam sinais radiológicos da doença, sendo que, somente $20 \%$ desta apresentam alterações consideradas como graves ou moderadas. O surgimento abaixo dos 40 anos é pouco comum, sendo que a sua frequência é maior após os 60 anos. A osteoartrose como doença osteoarticular de maior prevalência atinge aproximadamente 3,5\% da população, após os 60 anos essa porcentagem chega aos 10\% (Peyron, 1979). Em relação aos achados radiográficos, $52 \%$ da população adulta apresentam osteoartrose de joelhos e deste total 20 \% com quadro moderado ou grave (Lawrence, 1966). A faixa etária dos 75 aos 79 anos, as alterações radiográficas relacionadas à osteoartrose de joelho tem uma incidência de 13,8\% (Lawrence et al, 1989). A incidência desta patologia aumenta com idade, estimando-se atingir $85 \%$ da população até os 64 anos sendo que, aos 85 anos ela é universal (Organização Mundial de Saúde, Década do Osso e da Articulação-Movimento Articular 2000-2010).

Neste estudo epidemiológico (Srikanth et al., 2005), os homens têm uma significante redução do risco de artrose de joelho e mão, mas um grande risco de degeneração do disco intervertebral na coluna cervical em comparação com as mulheres. As mulheres especialmente aquelas acima dos 55 anos têm um risco alto de desenvolver artrose de joelho, mas não em outras regiões do corpo. 
São considerados fatores de risco para a osteoartrose: idade, trauma, esforços, sexo feminino, defeitos congênitos, fraqueza da musculatura do quadril, antecedente de artropatia inflamatória, alterações endócrinas ou metabólicas e defeitos proprioceptivos (Holmgren, 1975).

A visão tradicional da artrose é que esta começa com uma lesão na cartilagem articular, a qual não é reparada. Contudo, a complacência diminuída no osso e nas estruturas periarticulares podem também iniciar o processo degenerativo. O processo de formação do osteófito na osteoartrose não é bem compreendido; as hipóteses atuais têm implicado em um aumento da vascularidade na cartilagem degenerada, congestão venosa devido a cistos subcondrais e trabéculas subcondrais espessadas e a descamação contínua da cartilagem articular. Cada uma dessas hipóteses pode explicar como esse crescimento ósseo contribui para a dor e perda de mobilidade.

O joelho é uma articulação complexa que compreende três compartimentos principais - o femorotibial medial, o femorotibial lateral e o femoropatelar sendo que todos eles podem ser afetados por alterações degenerativas. Os aspectos radiológicos destas alterações são semelhantes aos observados na osteoartrose do quadril, que incluem: estreitamento do espaço articular (geralmente um ou dois compartimentos), esclerose subcondral, osteofitose e formação de cisto (ou pseudocisto) subcondral (Greenspan, 2001).

Nas alterações morfológicas, a cartilagem articular perde sua natureza homogênea, a qual é rompida e fragmentada, com fibrilações, fissuras e ulcerações. Às vezes, com o avanço da patologia, não resta nenhuma cartilagem e áreas de osso subcondral ficam expostas (Moskowitz et al., 1973 e 1977) 


\subsection{A Classificação da Artrose}

Embora a inflamação articular esteja implicada na osteoartrose, ela surge em decorrência da degeneração articular substancial. A sinóvia de uma articulação osteoartrítica pode demonstrar alterações acentuadas similares àquelas observadas na artrite reumatóide. Critérios clínicos e radiográficos segundo o Colégio Americano de Reumatologia (Altman et al., 1986).

1. Dor nos joelhos na maior parte dos dias do último mês

2. Osteófitos à radiografia

3. Líquido sinovial típico de osteoartrose

4. Idade $>/ 40$ anos

5. Rigidez matinal com duração $>/ 30$ minutos

6. Crepitação na movimentação ativa admite-se osteoartrose quando estão presentes os itens 1,2 ou $1,3,5,6$, ou $1,4,5,6$

Outra classificação utilizada é a de Ahlback modificada por (Keyes et al, 1992) onde são usadas radiografias ântero-posteriores em posição de esforço.

\begin{tabular}{|l|l|}
\hline Grau Radiografia ântero-posterior com & Radiografia em perfil \\
esforço & \\
\hline Grau1- Redução do espaço articular & \\
\hline Grau2 - Obliteração do espaço articular & \\
\hline Grau3 - Atrito do Platô Tibial < 5 mm & Parte posterior do platô intacta \\
\hline Grau4 - Atrito entre 5 e 10 mm & Atrito se estende à parte posterior do platô \\
\hline Grau5 - Subluxação grave da tíbia & Subluxação da tíbia > $10 \mathrm{~mm}$ \\
\hline
\end{tabular}

Legenda: Avaliação radiográfica analisando pelo grau de lesão 
O grau 2 é critério para definir a doença, enquanto que no grau 3 observa-se evidências de estreitamento do espaço articular, correspondendo à doença clinicamente identificada para designar a osteoartrose. Embora as evidências radiográficas de estreitamento do espaço articular e a presença de osteófitos possam ajudar a confirmar o diagnóstico e classificar o estágio da osteoartrose, os critérios clínicos para osteoartrose de quadril e joelho são descritos em termos de dor e limitação da mobilidade.

A radiografia acrescenta muito pouca à precisão do diagnóstico clínico e não há uma associação clara entre achados radiográficos em relação à função ou dor. $\mathrm{Na}$ osteoartrose do joelho, a força muscular e a dor explicam melhor a perda funcional em ralação aos achados radiográficos.

\subsection{Fisiopatologia da Artrose}

A osteoartrose degenerativa começa com um desgaste na superfície articular. A superfície lisa normal da cartilagem sofre um processo de descontinuidade associada à quebra das arcadas das fibras do colágeno e a superfície, então se torna irregular. A fricção contra a superfície irregular acaba gerando partículas de cartilagem articular, que por sua são derramadas na articulação e absorvidas pela sinóvia onde causaram uma resposta inflamatória, que o paciente sentirá como um enrijecimento ou dor na articulação depois de exercício (Rebelato e Morelli, 2007).

Existe outra classificação mais ampla, na qual a osteoartrose é dividida em uma forma primária ou idiopática e uma forma secundária associada a fatores bem determinados para desenvolvimento da osteoartrose. 
A osteoartrose primária inclui várias afecções diferentes. As mulheres brancas são as mais freqüentemente afetadas, com início entre a quinta e a sexta décadas de vida. $\mathrm{O}$ envolvimento poliarticular acontece nessa fase. $\mathrm{O}$ início pode ser relativamente súbito com articulações interfalângicas distais quentes e inflamadas (Rebelato e Morelli, 2007). Esta a única doença articular com episódio inflamatório sem repercussão sistêmica (Giorgi, 2005).

A osteoartrose secundária pode apresentar-se com a obesidade; como um contorno anormal de superfícies articulares devido às fraturas mal consolidadas, mau alinhamento das articulações por deformidades e alteração da anatomia por cirurgia prévia, especialmente meniscectomia.

A irritação sinovial provavelmente é devida à liberação de enzimas intracelulares, inclusive lisoenzimas que produzem hiperemia e uma resposta celular nas camadas sinoviais. A sinóvia pode também produzir enzimas degradativas e mediadores humorais, como a interleucina 1, que podem influenciar na atividade condrocitária e levar a produção de radicais livres e a deposição de imunocomplexos. (Rebelato e Morelli, 2007)

À medida que os proteoglicanos são perdidos, a cartilagem articular perde sua rigidez e elasticidade compressiva, o que por sua vez resulta na transmissão de forças compressivas para o osso subjacente. As alterações nos proteoglicanos da cartilagem também afetam negativamente a habilidade da cartilagem em formar uma película na sua superfície quando são colocados cargas sobre a articulação. A síntese de colágeno está aumentada inicialmente, embora haja uma mudança das fibras de colágeno do tipo II para uma proporção maior de colágeno do tipo I, o que é comumente encontrado na pele e no tecido fibroso. E à medida que a cartilagem é destruída, o espaço articular se estreita. 
Além disso, uma das primeiras alterações observada na cartilagem é a leve fragilização ou descamação das fibras de colágeno superficiais. A fragilização profunda ou fibrilamento do terço superficial da cartilagem vem em seguida, e ocorre em áreas de maior sustentação de peso. A cartilagem pode se degenerar até que o osso subcondral fique exposto. $\mathrm{O}$ osso subcondral, por sua vez, pode se tornar esclerótico e mais rígido que o osso normal. Essas alterações na cartilagem e no osso resultam em um aumento da fricção, assim ocasionando assim, uma diminuição na capacidade de absorção de choque e consequentemente um maior impacto ao se colocar uma carga sobre a articulação. Todo esse processo leva a uma disfunção motora e ao surgimento do processo álgico

\subsection{O agente físico no tratamento}

O agente físico tem uma função de diminuir a dor, atuando na modulação da liberação de mediadores inflamatórios, regulando a dor no nível da medula espinal, alterando a condução nervosa ou aumentando os níveis de opiopeptinas. De forma indireta reduzir a dor pela redução da sensibilidade do sistema de fuso muscular, modificando o tônus vascular e a taxa de fluxo sanguíneo, reduzindo, assim, o edema ou a isquemia (Ernest et al., 1994 e McMaster et al., 1980). Os agentes físicos podem reduzir a dor ao colaborarem na resolução da causa subjacente da sensação dolorosa.

A eletroterapia também controla a dor em parte ao estimular a liberação de opiopeptina na medula espinal em níveis mais elevados (Bassbaum et al., 1978). Agentes físicos utilizados isoladamente ou em conjunto podem também remediar a dor. 
A National Institute for Health and Clinical Excellence (NICE, 2008), recomenda a TENS no tratamento de paciente com osteoartrose de joelho em relação à diminuição da dor e da rigidez especialmente em tratamento de curto prazo. E que os profissionais deveriam considerar como um complemento ao tratamento de base para o alívio da dor.

\subsection{Tratamento, TENS e Artrose}

Os tratamentos clínicos utilizados, para o alívio dos sintomas álgicos, na osteoartrose formam um arsenal composto por: fármacos sintomáticos de ação rápida, os analgésicos narcóticos e não narcóticos, os medicamentos antiinflamatórios não hormonais e hormonais e a utilização de ácido hialurônico via intra-articular. Nas intervenções não farmacológicas, os aspectos como: a educação dos pacientes e familiares, a reabilitação e os exercícios, a redução dos fatores mecânicos sobre a articulação e as terapias complementares está colocada também como opção coadjuvante do tratamento. (Giorgi, 2005)

A origem do uso terapêutico da eletricidade na medicina vem da era socrática com objetivo tratar artrite e cefaleia no qual se utilizava a energia produzida pelo peixe elétrico, para diminuição de sintomas aos pacientes.

Um grande número de pesquisas demonstrou que a estimulação elétrica pode modular a dor (Chabal et al., 1988 e Cheing et al., 2005). O tipo de osteoartrose que a pesquisa pretende atender é tanto o compartimento femorotibial e femoropatelar

A estimulação elétrica transcutânea (TENS), desde sua introdução em 1967, tem sido utilizada intensivamente como modalidade terapêutica para o alívio da dor na 
osteoartrose, sendo que o mecanismo exato da neuromodulação da dor não está definitivamente esclarecido. Na década de sessenta com advento da teoria da comporta da dor de (Melzack e Wall, 1965), combinado com geradores eletrostáticos e condensadores, acabaram por recolocar a eletroterapia como método de tratamento.

Esses equipamentos surgiram na década de 1970 e atingiram grande popularidade devido ao seu custo reduzido, mas também, pelo forte impacto causado por pesquisas que envolviam o estudo da dor. A divulgação da "teoria da comporta do controle da dor" de (Melzack \& Wall, 1965), juntamente com o aumento na freqüência de dores crônicas na população mundial, e a associação com as pesquisas que mostravam alterações patológicas encontradas nos nervos que sofreram lesões, levaram a uma justificativa cientifica para a aplicação de impulsos elétricos em nervos lesionados, o que transformou os aparelhos da TENS em um dos recursos mais utilizados na prática da fisioterapia.

Embora, a maioria dos estimuladores elétricos usados hoje seja essencialmente unidades TENS, na verdade esses equipamentos têm características de corrente muito parecidas com outras formas de estimulação neuromuscular. Eles são constituídos de geradores de correntes pulsáteis, bifásicas simétricas ou assimétricas de forma retangular.

A capacidade de reversão da polaridade permite que esses aparelhos permaneçam ligados durante horas seguidas, sem que isso implique em um maior risco de dano tissular. Os aparelhos da TENS possuem tipicamente dois canais de estimulação. O que permite a utilização de quatro eletrodos de tamanhos variados, com controle independente de amplitude para cada canal. Normalmente, os controles de duração de pulso e freqüência de estimulação, também, estão disponíveis.

Nas últimas décadas, os aparelhos da TENS têm se popularizado, por se mostrar um recurso prático, não invasivo, de baixo custo e com boa eficácia no alívio da dor. Contudo, 
ainda existem muitas controvérsias acerca dos seus benefícios, pois as pesquisas clínicas que envolvem avaliação da dor, em geral são difíceis de serem controladas. O mecanismo exato de inibição da dor baseia-se na compreensão da patologia da lesão e das alterações subseqüentes que podem ocorrer nas vias sensoriais.

$\mathrm{Na}$ Teoria da Comporta há interação das fibras grossas mielinizadas c com a substância gelatinosa do corno posterior da medula espinhal; este mecanismo constitui uma das bases para a alteração da percepção da dor. Quando impulso aferente via fibras grossas mielinizadas são de intensidade maior do que os das fibras c, os interneurônios da substância gelatinosa são ativados e inibem as aferências dolorosas pré-sinápticas no nível segmentar, isto é: fecha a comporta.

Muitos estudos colocam que a inibição segmentar está à frente do processo de analgesia mediada pela TENS. A inibição da TENS de alta frequência é parcialmente impedida pela espinalização a qual remove as influências inibitórias descendentes (Woolf et al, 1980).

Já em pesquisa realizada por (Campbell e Taub, 1973), sugere que estimulação da TENS por alta frequência resulta em uma condição de bloqueio ou fadiga de fibra $A \delta$.

Os efeitos fisiológicos da eletroterapia sobre o sistema neuromúsculo-esquelético são: analgesia, estimulação muscular, vasodilatação, redução de edema, diminuição da inibição reflexa, facilitação na cicatrização de lesões em tecidos moles e facilitação da consolidação de fraturas (Brandão et al, 2005).

Os mecanismos encefálicos explicam também o efeito analgésico da estimulação pela TENS nas situações nas quais a aferência normal é diminuída ou perdida. Como na TENS, a entrada aferente é suplementada e ativa mecanismos do mesencéfalo que inibem a transmissão da dor. Na teoria neurofarmacológica, desde a descoberta das endorfinas e 
encefalinas em 1975, o processo de entendimento do tratamento está mais compreensível. Acredita-se que a TENS aumente a concentração, destes e de outros neurotransmissores inibitório resultando em elevação do limiar da dor. O mecanismo do bloqueio periférico baseia-se na teoria que a habilidade da TENS em alterar a transmissão dos impulsos dolorosos via antidrômica.

Em uma metaanálise produzida pelo painel da Phyladelphia observou-se uma forte evidência da TENS no controle da dor, mas o que não está claro se a utilização da TENS melhora a função física (Philadelphia Panel, 2001).

Os autores (wang et al., 1992 e Han et al., 1991), em seus estudos notaram que o tempo decorrido de analgesia produzida pela TENS é parecido ao que é repercutido pelos opióides endógenos

Em um estudo comparando o efeito analgésico da TENS e a corrente interferencial chegou-se a conclusão que a TENS é mais efetiva em aumentar o limiar para dor em sujeito saudáveis expostos ao frio, sendo que a diferença foi estatisticamente significante para a TENS (Shanahan et al, 2006).

Em estudo que avaliou o tratamento com diclofenaco de sódio comparando com a TENS como primeira intervenção isolada, mostrou-se superior na redução da dor como também na melhora da deambulação em pacientes com osteoartrose de joelho, com grau suave a moderado e que não está associado à destruição de cartilagem, o que é sugerido quando da administração por longo período de drogas antiinflamatório não esteroidais (Lone et al., 2003).

Estimulação elétrica nervosa transcutânea é sugerida como possível tratamento, juntamente com o exercício em pacientes que estão sofrendo as complicações da osteoartrose (NICE, 2008). No painel da Philadelphia apresenta forte evidência da TENS 
com relação a sua possibilidade de aplicação para tratar dor no joelho com osteoartrose (Philadelphia Panel, 2001).

Pacientes com exame radiográfico sinalizando grau de osteoartrose nível 2-4 e intensidade de dor acima de $50 \mathrm{~mm}$ pela escala visual analógica VAS, um regime de 2 a 4 semanas é estatisticamente significante para alívio da dor em um curto período de tratamento (Bjordal et al, 2007).

Em estudo desenvolvido que comparou três frequências juntamente com grupo placebo observou-se que, em relação à amplitude de movimento do joelho todas as frequiências ocorreram melhora e que foi também superior ao efeito placebo (Law e cheing, 2004)

Vários tipos de aparelhos da TENS foram introduzidos nos últimos anos. Com a variação da largura do pulso e da freqüência, permitiu-se uma escolha terapêutica mais adequada e eficaz para um doente em particular. A assim chamada unidade HIGH-TENS (TENS convencional) caracterizada pelo pulso de 50 a $80 \mathrm{~ms}$ e freqüência de 80 a $100 \mathrm{HZ}$, a analgesia é percebida em menos de 10 minutos e os efeitos duram até $48 \mathrm{~h}$, tem seu mecanismo de ação ligado a modulação da dor, provavelmente pelo aumento na concentração de encefalinas no líquido cérebro espinhal.

A unidade LOW-TENS (TENS Acupuntura) com pulso mais largo (>200 ms), e freqüência menor (0,5-10 HZ), produz analgesia após 15 a 30 minutos de aplicação. O efeito pode ser revertido com administração de naloxona, o que implica no conceito de que o efeito analgésico do LOW-TENS é obtido através da liberação de $\beta$-endorfina (Melzack e Stillwell, 1977).

Em estudo com proposta de avaliar se a TENS reduziria a hiperalgesia primária em ratos submetidos à inflamação aguda nos joelhos por substância injetada intraarticular de 
uma mistura de kaolin e carrageenan, a TENS clinicamente segundo os dados da pesquisa depois que passou a fase aguda da inflamação pode ser mais efetivo em reduzir dor e hiperalgesia (Vance et al, 2007)

A aplicação da TENS em alta frequência diminui significativamente a concentração de aspartato e glutamato no fluído extracelular no corno dorsal da medular espinhal de animais com inflamação articular, sugerindo que os receptores deltas opióides estariam envolvidos e que em articulação sem inflamação o mesmo resultado não ocorreu. Em baixa frequência essa diminuição não foi observada com relação à concentração de aspartato e glutamato. (Sluka et al, 2005a).

Alta freqüência e baixa intensidade são aplicadas para o tratamento da dor segmentar; na situação de baixa freqüência e alta intensidade ocorre liberação de opióides endógeno; já com alta freqüência, o resultado produzido é um potente efeito analgésico. A combinação de ambos, alta freqüência com alto estímulo, pode atuar sobre o nível segmentar, assim como o nível supra-espinhal.

Os locais onde são colocados os eletrodos são ainda comumente escolhidos através de erros e acertos, porque não há um método que prevê a eficiência de certa localização para um dado paciente. Os locais mais comumente utilizados são os dermátomos, área suprida pelos nervos periféricos, locais de acupuntura, ou a própria área dolorida. Similarmente os parâmetros dos estímulos são escolhidos empiricamente.

A dor crônica é freqüentemente associada com patologias orgânicas pobremente definidas. Por outro lado, a dor crônica somatogênica ou psicogênica é menos responsiva ao tratamento com TENS do que a dor de origem neuropática.

São descritos poucos efeitos colaterais e ou contraindicação para o uso da TENS. Cerca de $10 \%$ dos pacientes registram agravamento da dor como resultado do tratamento 
da TENS. Admite-se que esse problema seja resultado da liberação de histamina e pode ser controlado com frequiência baixa e com estímulos menores do que $80 \mathrm{HZ}$. Micropontos de queimaduras e reações alérgicas ao esparadrapo ou gel são os únicos efeitos colaterais reconhecidos que podem ocorrer. A única contra indicação absoluta reconhecida seria colocar os eletrodos sobre o seio carotídeo em pacientes com marca-passo cardíaco de demanda.

A Teoria da Comporta contribuiu para avanços nas pesquisas sobre a eletrofisiologia da dor. O foco central no desenvolvimento da pesquisa no corno dorsal da medula, é que nessa região estaria a modulação da transmissão do impulso nervoso. O aspecto chave da teoria foi o efeito inibitório da fibra aferente A sobre a fibra C.

O efeito principal e direto de todas as unidades de TENS ocorre em nível celular. A membrana do nervo periférico tem um potencial de repouso que é negativo internamente e positivo externamente, que constitui o potencial de ação sensitivo. As unidades TENS também afetam o sistema biológico em níveis teciduais, segmentares e sistêmicos, porém de modo indireto. O nível celular inclui a excitação de fibras sensoriais de condução da dor. Provavelmente as grandes fibras A e B, mielinizadas, fornecem o caminho para a TENS. Essas fibras de maior condução são altamente sensíveis à estimulação elétrica e conduzem rapidamente o impulso elétrico até a medula espinhal. As fibras C conduzem os estímulos dolorosos e por serem pequenas não mielinizadas e de condução lenta, seriam incapazes de transmitir a TENS. A TENS pode ser utilizado como uma corrente elétrica cuja principal função é modular a dor via estimulação nervosa, a TENS trabalha de forma a competir com o estímulo doloroso, cujo objetivo é alcançar mais rapidamente o centro nervoso. 
Os caminhos para alcançar o efeito esperado são por axônios específicos, sendo que para o desenvolvimento do tratamento depende de três fatores que interagem; a propriedade anatômica das fibras nervosas, a superfície da pele e a intensidade da corrente externa. A colocação dos eletrodos deve observar a proximidade da área a ser tratada, podendo construir outras formas de posicionamento dos eletrodos prestando atenção ao trajeto dos nervos periféricos que também levam a informação nociceptiva.

Quatro tipos de aparelhos TENS são usados na prática clínica. O primeiro é de Alta freqüência que se caracteriza com 40 a $150 \mathrm{~Hz}$, pulsos de largura entre 50 a $100 \mathrm{~ms}$, intensidade moderada; o segundo é o de Baixa Freqüência e que se constitui por ondas de 1 a 4Hz, pulsos de largura entre 100 a 400 ms e alta intensidade; O terceiro é de Freqüência de explosão que possui ondas de 1 a $4 \mathrm{~Hz}$, pulsos de largura entre 100 e $250 \mathrm{~ms}$ e alta intensidade; O quarto é de hiperestimulação contendo ondas de 1 a $4 \mathrm{~Hz}$, com pulsos de largura de 10 a $500 \mathrm{~ms}$ e alta intensidade (Osiri et al, 2000)

A TENS trabalha com quatro níveis de intensidade de estímulos: sub-sensório, sensório, motor, nociceptivo.

O nível subsensório da TENS utiliza um período da carga elétrica de amplitude insuficiente para alcançar o limiar sensório e despolarizar os axônios dos nervos periféricos ou despolarizar a membrana muscular. (Robinson e Snyder-Mackler, 1995)

O nível sensório é definido como a estimulação em ou acima do limiar sensitivo e abaixo do limiar motor e é primeiramente indicado para dor aguda e subaguda, mas também tem utilidade em condições crônicas. (Robinson, Snyder-Mackler, 1995). 
O nível motor de estimulação é usado primariamente para controle de dor não aguda. A amplitude da TENS é alta e o suficiente para produzir contração muscular visível ( Robinson e Snyder-Mackler, 1995 e Cameron, 2003).

O questionário McGill é considerado um dos melhores instrumentos para a avaliação das dimensões sensitiva-discriminativa, afetiva-motivacional e cognitivaavaliativa da dor, (Pimenta e Teixeira, 1996). Na avaliação final dos pesquisadores que validaram o questionário Mcgill para a língua portuguesa, o sub item miscelânea foi incluído o que totalizou 20 subgrupos com 78 descritores (Maiani e Sanavio, 1985).

Dos 78 descritores que compõem o questionário de McGill, 42 (53,9\%) referem-se ao aspecto sensitivo da dor; $14(17,9 \%)$ ao componente afetivo, $5(6,4 \%)$ a avaliação da experiência dolorosa e $17(21,8 \%)$ ao subgrupo de miscelânea. Tem sido motivo de questionamentos a distribuição desproporcional dos descritores entre os 3 componentes (sensitivo, afetivo e avaliativo), acrescido do fato de que a maioria dos descritores do subgrupo miscelânea é de caráter sensitivo. Acredita-se que, decorrente desta diferença de proporções, o doente pode ser impedido a escolher mais descritores (Chapman et al, 1985). Os sub-grupos de 1 a 10 representam respostas sensitiva à experiência dolorosa ( tração, calor, torção, entre outros): os descritores dos sub-grupos de 11 a 15 são respostas de caráter afetivo ( medo, punição, respostas neurovegetativas, etc.); o sub-grupo 16 é avaliativo (avaliação da experiência global) e os de 17 a 20 são miscelânea (Pimenta e Teixeira, 1996) . 
Devido a importância da articulação do joelho na função corporal e sua relação com as atividades da vida diária. Os pacientes com osteoartrose de joelho sofrem não somente pelo problema localizado, existe uma alteração funcional global que pode levar a processos dolorosos em outras articulações, a importante orientação e avaliação no paciente, seja explicando como é sua dor, e ouvir como este estímulo doloroso prejudica sua vida é de fundamental significância.

O objetivo do presente estudo foi avaliar o efeito da estimulação elétrica nervosa transcutânea nível sensório para tratamento de dor em pacientes com diagnóstico de OA em joelhos, utilizando escalas de avaliação de dor, escala de avaliação funcional. 
3 MÉTODO 


\subsection{Sujeitos}

Foram estudados 10 pacientes com diagnóstico de osteoartrose de joelho, no qual foi pesquisado junto ao prontuário do serviço de ortopedia e traumatologia, especificamente grupo de joelho, ligado também ao serviço de fisioterapia. Desenvolveu-se uma entrevista prévia por telefone convidando o paciente a participar de um protocolo de pesquisa em pacientes com osteoartrose de joelho através de uma modalidade fisioterapêutica, a eletroterapia, especificamente com a (TENS) estimulação elétrica nervosa transcutânea, com um total de 10 sessões de 30 minutos por sessão, sendo que cada paciente foi entrevistado com 3 questionários neste período de 10 sessões. Se no momento da entrevista o paciente relata algum dos critérios abaixo seria excluído do protocolo: déficits auditivos e/ou visuais que impossibilitem informar sobre efeitos e/ou desconfortos ou visualizar a escala de dor, pele atrófica na região onde serão colocados os eletrodos, alergia aos eletrodos ou aos géis, marca-passo cardíaco, déficits cognitivos que interfiram na aplicação dos questionários que serão utilizados na avaliação da dor, sequelas de AVC nos membros inferiores. Os pacientes foram selecionados no ambulatório do joelho do Instituto de Ortopedia e Traumatologia da Faculdade de Medicina da Universidade de São Paulo no período de março de 2008 a junho de 2010 e todos os pacientes foram orientados com relação ao Termo de Consentimento livre e esclarecido

pelo Comitê de Ética do Hospital (nº 120/09). 


\subsection{Estruturação do Protocolo}

Após análise dos prontuários, desenvolveu-se uma entrevista prévia por telefone convidando o paciente a participar de um protocolo de pesquisa em pacientes com osteoartrose de joelho através de uma modalidade fisioterapêutica, a eletroterapia, especificamente com a (TENS) estimulação elétrica nervosa transcutânea, no qual o alvo de tratamento foi o joelho. O tratamento foi estruturado utilizando um ciclo de 10 sessões de 30 minutos em cada paciente, em um período de 3 semanas e 1 dia, sendo que cada paciente passou por questionário de avaliação funcional na $1^{\mathrm{a}}$ sessão, na $5^{\mathrm{a}}$ e na $10^{\mathrm{a}}$ sessão. A escala de avaliação da dor foi mensurada em todas as 10 sessões antes e depois do tratamento com a TENS. Aparelho de eletroestimulação transcutânea do nervo (TENS) com as devidas credenciais da ANVISA sob o № 10245230014, empresa certificada NBR ISSO 9001 e autorização de funcionamento da empresa no Ministério da Saúde № 1024523. KLD Biosistemas Equipamentos Eletrônico. Nome do equipamento é Endophasys que se destina tanto para o eletrodiagnóstico e estimulação neuromuscular funcional de médias e baixas frequências que pode ser utilizado em todas as áreas de atuação da eletroterapia, tais como ortopedia, traumatologia, neurologia, fisiatria, fisioterapia, medicina esportiva. 


\subsection{Estimulação com a TENS}

O paciente após a entrevista e a primeira avaliação, foi agendado a primeira sessão. Os parâmetros da corrente elétrica de baixa frequência a TENS, foi ajustada da seguinte forma, com uma frequência de $80 \mathrm{~Hz}$, duração do pulso de $140 \mu \mathrm{s}$, adequada ao nível sensório, em um período de 30 minutos em cada sessão, em média 3 sessões por semana e mais 1 sessão para conclusão do tratamento, totalizando 10 sessões.

E o nível sensório ou convencional que é caracterizado por correntes de baixa freqüência $80 \mathrm{~Hz}$ e largura de pulso de $140 \mu$ segundos, caracterizado por pulsos de baixa amplitude e curta duração para controle da dor, o tempo de aplicação será de 30 minutos.

Utilizei quatro pontos de acupuntura com referência para o posicionamento dos eletrodos com a devida relação de inervação com o joelho, os pontos a serem aplicados nos joelhos serão E35, M-MI-27, BP9, VB34.

E35, a localização anatômica do ponto é joelho fletido, o ponto situa-se em depressão lateral ao ápice da patela, ao lado do ligamento patelar, a inervação deste ponto é superficialmente com o ramo infrapatelar do nervo safeno, ramos cutâneos anteriores do nervo femoral e nervo cutâneo lateral da coxa e profundamente com ramos do nervo fibular comum;

M-MI27, situa-se no joelho, na base da patela, no meio do tendão do quadríceps, a inervação: relaciona-se superficialmente com os ramos cutâneos anteriores do nervo 
femoral e, profundamente, com os ramos articulares para o joelho, do nervo fibular comum;

BP9 situa-se em uma reentrância óssea que se encontra sob a margem inferior do côndilo medial da tíbia e o músculo gastrocnêmio, a inervação: relaciona-se superficialmente, com o ramo infrapatelar do nervo safeno e, profundamente, com os ramos musculares no nervo tibial;

VB34 situa-se no terço superior da face lateral da perna, em uma reentrância muscular, localizada distalmente, e à frente da cabeça da fíbula, a inervação: relaciona-se superficialmente, com os ramos do nervo cutâneo lateral da sura e profundamente, com os ramos articulares do nervo fibular comum. 


\subsection{Avaliação da dor}

A avaliação da dor foi através do questionário da Dor McGill - Melzack, composto por quatro itens principais: 1 - qual a localização de sua dor?, 2 - Qual o tipo?, 3 - Como ela se altera no decorrer do tempo?, 4 - Qual a sua intensidade?

1 - Estes dados foram coletados, mas, foi excluído por motivo de dificuldade de compreensão do paciente.

2 - Os termos deste item descreve sua dor atual. Marque com um círculo apenas aqueles que melhor a descreve. Deixe de lado qualquer categoria não adequada. Utilize apenas um termo de cada categoria, o que melhor se aplica à sua dor.

3 - Este item descreve como a sua dor muda com o tempo usando 3 perguntas para o paciente descrever o padrão de sua dor, que tipo de coisas alivia sua dor, que tipo de coisas aumenta sua dor.

4 - Este item descreve quão forte é a sua dor, estão sob uma tabela com 5 palavras que representam a dor de intensidade crescente.

A seguir a utilização de uma escala analógica visual da dor que permite ao paciente quantificar visualmente a magnitude de sua dor sobre uma linha contínua de $10 \mathrm{~cm}$ sendo que a esquerda da linha o descritor sem dor e a direita o descritor dor máxima. Outra escala analógica visual da dor em que o paciente deveria marcar em uma régua de 0 a 10 , sendo que $0,1,2$ como descritores leves associados a uma caricatura para descrever cada nível; 3 , 4, 5, 6, 7 para o nível moderado, 8, 9, 10 para o nível intenso, sendo que a pergunta é onde o seu "nível de dor" foi mais intenso em qualquer ocasião. 


\subsection{Questionário de avaliação funcional}

O questionário a seguir foi elaborado para determinar os sintomas e as limitações que você sente por causa do joelho ao executar suas atividades diárias habituais. Por favor, responda cada questão assinalando à afirmativa que melhor descreve você durante os últimos 1 a 2 dias. Para uma questão, mais de uma das afirmativas podem descrevê-lo, mas, por favor, assinale SOMENTE aquela que melhor o descreve durante as suas atividades cotidianas. Questionário composto por 22 questões as quais foram aplicadas nos três momentos de avaliação em cada paciente do protocolo de pesquisa.

\subsection{Análise estatística}

Para entrada dos dados dos questionários foi utilizado o gerenciador de bancos de dados Access da Microsoft Office. Para análise estatística foi utilizado o programa SPSS (Statistical Package for the Social Sciences).

Análise dos dados obtidos

Para análise das variáveis apresentadas, com as características de serem três amostras pareadas, com distribuição não normal e dados ordinais, foi escolhido o Teste de Friedman (ANOVA com medidas repetidas não paramétricas). As variáveis com duas amostras pareadas, com distribuição não normal foram analisadas com o teste de 
Wilcoxon. As variáveis com distribuição normal foram analisadas com o teste "t" de Student.

Considera-se que houve diferença estatisticamente significativa entre as amostras quando se obtém um valor de $\mathrm{p}=<0,05$.

Descrição da amostra

Um grupo de 10 pacientes do sexo feminino com osteoartrose de joelho foi avaliado em três momentos. A média de idade foi de 67 anos, com desvio padrão de 12,2, com máximo de 83 e mínimo de 51. 


\section{RESULTADOS}


Os participantes do estudo totalizaram 10 pacientes. Os pacientes tinham a média de 67 anos \pm 12 anos, todos do sexo feminino.

A relação de como a dor muda com o tempo, mostrou uma diminuição na quantidade de caracteres marcados na ficha de avaliação nos 3 intervalos de avaliação. Indicando a possibilidade de evolução positiva no decorrer do tratamento com a TENS.

Através do questionário que tem por objetivo avaliar o tipo de dor nas diferentes entrevistas. $\mathrm{O}$ total de palavras que poderiam explicar o tipo de dor na $1^{\mathrm{a}}$ entrevista foi de 178 nos 10 pacientes estudados. Na $2^{\mathrm{a}}$ entrevista com mesmos 10 pacientes, para os mesmos períodos passou para 84 palavras. $\mathrm{Na} 3^{\mathrm{a}}$ entrevista que aconteceu após a $10^{\mathrm{a}}$ sessão foram escolhidos 34 caracteres para explicar o tipo de dor que apresentavam ao final do protocolo de pesquisa.

No questionamento de que tipo de coisas alivia a sua dor, a medicação na $1^{\text {a }}$ entrevista foi o item escolhido de 6 pacientes no total de 10 pacientes avaliados. Já na $2^{\mathrm{a}}$ entrevista o item medicação foi escolhido por 2 em 10 pacientes avaliados. $\mathrm{Na} 3^{\text {a }}$ avaliação o item medicação foi escolhido somente 1 vez em 10 pacientes avaliados.

A TENS foi relatada pelos pacientes como condição que aliviou a dor em 3 pacientes dos 10 pacientes estudados, isso quer dizer que o paciente informou que realmente a TENS estava diminuindo a dor, não foi solicitado ao paciente que interrompesse o tratamento medicamentoso, a intenção foi confrontar a TENS com a medicação.

No questionamento de que tipo de coisas aumenta a sua dor, a situação de estar em movimento foi o que mais os pacientes relataram. A atividade da marcha em si aumenta a 
dor. O que ficou evidente foi a diminuição dos pacientes em relatar a deambulação com fator agravante da dor na $3^{\mathrm{a}}$ avaliação.

No item, a inteligência do paciente somente orientou em como conduzir o ciclo da terapia, relação terapeuta-paciente.

Em relação ao item que questionava quão forte é a sua dor: A pergunta era qual palavra descreve a sua dor exatamente neste momento? Podemos dizer que não houve diferenças estatisticamente significativas nas amostras analisadas. A $2{ }^{\text {a }}$ pergunta foi, qual palavra a descreve no pior momento? Podemos dizer que não houve diferenças estatisticamente significativas nas amostras analisadas. Continuando neste item a $3^{\mathrm{a}}$ pergunta: qual palavra descreve a pior dor de dente que você já sentiu? Podemos dizer que não houve diferenças estatisticamente significativas nas amostras analisadas. $\mathrm{Na} 4^{\mathrm{a}}$ pergunta: qual palavra descreve a pior dor de cabeça que você já sentiu? Podemos dizer que não houve diferenças estatisticamente significativas nas amostras analisadas. $\mathrm{N} 5^{\mathrm{a}}$ pergunta: qual palavra descreve a pior dor de estômago que você já sentiu? Podemos dizer que não houve diferenças estatisticamente significativas nas amostras analisadas. No Questionário de Dor de McGill foram avaliados os seguintes descritores: o descritor sensitivo: neste caso, com o valor de $\mathrm{p}<0,0001$ podemos dizer que houve diferenças estatisticamente significativas nas amostras analisadas, a marcação deste descritor foi diminuindo durante o período de terapia que compreendia 10 sessões com a TENS e 3 avaliações neste período. Com o descritor afetivo: neste caso, com o valor de $p=0,001$ podemos dizer que houve diferenças estatisticamente significativas nas amostras analisadas, à marcação deste descritor foi diminuindo no período da terapia. Com o descritor avaliativo: neste caso, com o valor de $\mathrm{p}=0,001$ podemos dizer que houve diferenças estatisticamente significativas nas amostras analisadas, houve diminuição na 
marcação deste item durante a evolução da terapia. O descritor miscelânea: neste caso, com o valor de $\mathrm{p}=0,011$ podemos dizer que houve diferenças estatisticamente significativas nas amostras analisadas, houve diminuição na marcação deste descritor durante o período da terapia observado pelos 3 questionários. No índice de dor total: neste caso, com o valor de $\mathrm{p}<0,0001$ podemos dizer que houve diferenças estatisticamente significativas nas amostras analisadas. Em uma análise do grupo sensorial-discriminativo, o descritor vibração só foi citado na primeira entrevista juntamente com o descritor tremor, já o item latejante foi descrito na $1^{\mathrm{a}}$ entrevista 7 vezes, na $2^{\mathrm{a} e n t r e v i s t a} 4$ vezes, na $3^{\mathrm{a}}$ entrevista 2 , o que poderia indicar uma melhora de sintoma com a utilização da TENS; no descritor como batida foi citado uma na $1^{\mathrm{a}}$ e na $2^{\mathrm{a}}$ entrevista, o descritor como pancada foi citado somente na $1^{\mathrm{a}}$ entrevista; o descritor pontada foi citado 6 vezes na $1^{\mathrm{a}}, 3$ vezes na $2^{\mathrm{a}}$ e nenhuma vez na $3^{\mathrm{a}}$ entrevista análise feita juntamente com o tratamento em si. O descritor choque foi citado 3 vezes na $1^{\text {a }}$ entrevista, 4 vezes na $2^{\text {a }}$ e uma vez na $3^{\text {a }}$ entrevista, pela análise deste descritor na população estudada uma diminuição importante no seguimento da pesquisa. $\mathrm{O}$ descritor tiro foi citado 2 vezes na primeira entrevista e nas demais não foi; o descritor agulhada foi citado 6 vezes na $1^{\text {a }}$ entrevista, 1 na $2^{\text {a }}$ e 1 na $3^{\text {a }}$ entrevista; o descritor perfurante foi citado 3 na $1^{\mathrm{a}}$, 2 na $2^{\mathrm{a}}$ e 1 na $3^{\mathrm{a}}$ entrevista; o descritor punhalada foi citado somente na $2^{\mathrm{a}}$ entrevista; o descritor fina foi citado 5 vezes na $1^{\mathrm{a}}, 5$ na $2^{\mathrm{a}}$ e 3 na $3^{\mathrm{a}}$ entrevista; o descritor cortante foi citado 2 vezes na $1^{\mathrm{a}}$, 1 na $2^{\mathrm{a}}$ entrevista; o descritor beliscão foi citado 2 vezes na $1^{\mathrm{a}}, 4$ na $2^{\mathrm{a}}$ e 1 vez na $3^{\mathrm{a}}$ entrevista; o descritor foi citado 3 vezes na $1^{\mathrm{a}}$ entrevista e não foi mais citado nas demais; o descritor esmagamento foi citado 3 vezes na $1^{\text {a }}$ entrevista e não foi mais citado; o descritor fisgada foi citado 5 vezes na $1^{\text {a }}$ entrevista, 3 na $2^{\mathrm{a}}$ e 1 vez na $3^{\mathrm{a}}$ entrevista; o descritor puxão foi citado 1 vez na $1^{\mathrm{a}}$ e 1 vez 
na $2^{\mathrm{a}}$ entrevista; o descritor em torção foi citado 3 vezes na $1^{\mathrm{a}}$ entrevista e não foi mais citado; o descritor calor foi citado 3 vezes na $1^{\text {a }}$ e 1 vez na $2^{\mathrm{a}}$ entrevista; o descritor queimação foi citado na $1^{\mathrm{a}}$ entrevista 4 vezes, na $2^{\mathrm{a}}$, 2 vezes e na $3^{\mathrm{a}} 1$ vez; o descritor formigamento foi citado 6 vezes na $1^{\text {a }}$ entrevista e não foi mais pontuado; o descritor coceira foi citado 2 vezes na $1^{\text {a }}$ entrevista, 1 vez na $2^{\text {a }}$ e 1 vez na $3^{\text {a }}$; o descritor ardor foi citado 2 vezes na $2^{\mathrm{a}}$ entrevista; o descritor ferroada foi citado 3 vezes na $1^{\mathrm{a}}$ entrevista, 2 na $2^{\mathrm{a}}$ e 1 na $3^{\mathrm{a}}$ entrevista; o descritor mal localizada foi citado 3 vezes na $1^{\mathrm{a}}$ entrevista, 1 na $2^{\mathrm{a}}$ entrevista; o descritor dolorida foi citado 6 vezes na $1^{\text {a }}$ entrevista, 2 na $2^{\text {a }}$ entrevista; o descritor foi citado machucada foi citado 1 vez na $1^{\text {a }}$ entrevista; o descritor doída foi citado 2 vezes na $1^{\mathrm{a}}$ entrevista, 1 vez na $2^{\mathrm{a}}$ e 2 vezes na $3^{\mathrm{a}}$ entrevista; o descritor pesada foi citado 1 vez na $1^{\mathrm{a}}$ entrevista, 1 vez na $2^{\mathrm{a}}$ entrevista; o descritor sensível foi citado 4 vezes na $1^{\mathrm{a}}$ entrevista, 3 vezes na $2^{\text {a }}$ entrevista e 2 vezes na $3^{\text {a }}$; o descritor esticada foi citado 2 vezes na $1^{\mathrm{a}}, 2$ vezes na $2^{\mathrm{a}}$ entrevista; o descritor rachando foi citado 2 vezes na $1^{\mathrm{a}}$ entrevista.

O grupo afetivo-motivacional (subgrupos de 11 a 15 do questionário de dor McGill) descreve a dimensão afetiva nos aspectos de tensão, medo e respostas neurovegetativas (Pimenta \& Teixeira, 1996). O descritor cansativa foi citado 7 vezes na $1^{\text {a }}$ entrevista, 4 vezes na $2^{\mathrm{a}}$ e 2 vezes na $3^{\mathrm{a}}$ entrevista; o descritor exaustiva foi citado 2 vezes na $1^{\mathrm{a}}$ entrevista; o descritor enjoada foi citado 6 vezes na $1^{\text {a }}$ entrevista, 4 vezes na $2^{\text {a }}$ e 2 vezes na $3^{\text {a }}$ entrevista; o descritor sufocante foi citado 3 vezes na $1^{\text {a }}$ entrevista; o descritor castigante foi citado 2 na $1^{\mathrm{a}}$ entrevista, 2 vezes na $2^{\mathrm{a}}$ entrevista; o descritor atormenta foi citado 5 vezes na $1^{\mathrm{a}}$, 1 vez na $2^{\mathrm{a}}$ e 1 vez na $3^{\mathrm{a}}$ entrevista; o descritor cruel foi citado 2 vezes na 1 entrevista; o descritor amedrontadora foi citado 3 vezes na $1^{\mathrm{a}}$ entrevista, 1 vez na $2^{\mathrm{a}}$ e 1 vez na $3^{\mathrm{a}}$ entrevista, o descritor apavorante foi citado 2 vezes na $1^{\mathrm{a}}$ entrevista, o descritor aterrorizante foi citado $1 \mathrm{vez}$ na $1^{\mathrm{a}}$ entrevista, o descritor maldita foi citado 1 vez na $1^{\mathrm{a}}$ 
entrevista; o descritor miserável foi citado 3 vezes na $1^{\mathrm{a}}$ entrevista e 1 vez na $2^{\mathrm{a}}$ entrevista; o descritor que cega foi citado $1 \mathrm{vez}$ na $3^{\mathrm{a}}$ entrevista. Realizado esta análise pode-se sugerir que a medida que as avaliações foram sendo feitas, observou uma redução na quantidade de descritor marcado durante as entrevista, o que sugere uma redução do quadro doloroso com a aplicação da TENS em pacientes com OA de joelho.

O descritor do componente cognitivo-avaliativo (subgrupo 16) permite, ao doente, expressar a avaliação global da experiência dolorosa (Pimenta \& Teixeira, 1996). O descritor chata foi citado 2 vezes na $1^{\text {a }}$ entrevista e 1 vez na $3^{\text {a }}$ entrevista; o descritor que incomoda foi citado 6 vezes na $1^{\mathrm{a}}$ entrevista, 2 vezes na $2^{\mathrm{a}}$ e 1 vez na $3^{\mathrm{a}}$ entrevista; o descritor desgastante foi citado 2 vezes na $2^{\mathrm{a}}$ e 1 vez na $3^{\mathrm{a}}$ entrevista; o descritor forte foi citado 4 vezes na $1^{\text {a }}$ entrevista; o descritor insuportável foi citado 3 vezes na $1^{\text {a }}$ entrevista. Os subgrupos de 17 a 20 compreendem itens de miscelânea. Cada subgrupo tem uma proposta de avaliação qualitativa (Pimenta \& Teixeira, 1996). O descritor espalha foi citado somente 1 vez na $3^{\text {a }}$ avaliação; o descritor irradia foi citado 3 vezes na $1^{\text {a }}$ avaliação e 2 vezes na $2^{\mathrm{a}}$ avaliação; o descritor penetra foi citado 3 vezes na $1^{\mathrm{a}}$ avaliação e 2 vezes na $2^{\mathrm{a}}$ avaliação; o descritor atravessa foi citado 1 vez na $1^{\mathrm{a}}$ e 1 vez na $2^{\mathrm{a}}$ avaliação; o descritor aperta foi citado 3 vezes na $1^{\mathrm{a}}$ avaliação e 1 vez na $2^{\mathrm{a}}$ avaliação; o descritor adormece foi citado 1 vez na $1^{\text {a }}$ avaliação e 2 vezes na $2^{\text {a }}$ e 1 vez na $3^{\text {a }}$ avaliação; o descritor repuxa foi citado 5 vezes na $1^{\mathrm{a}}$ avaliação, 1 na $2^{\mathrm{a}}$ e 1 na $3^{\mathrm{a}}$ avaliação; o descritor fria foi citado 1 vez na $1^{\mathrm{a}}$ e 3 vezes na $2^{\mathrm{a}}$ avaliação; o descritor gelada foi citado 2 vezes na $1^{\mathrm{a}}$ avaliação e 1 vez na $3^{\mathrm{a}}$ avaliação; o descritor aborrecida foi citado 4 vezes na $1^{\mathrm{a}}$ avaliação, 6 vezes na $2^{\mathrm{a}}$ avaliação; agonizante foi citado 2 vezes na $1^{\text {a }}$ avaliação; o descritor pavorosa foi citado 1 vez na $1^{\mathrm{a}}$ avaliação; o descritor torturante foi citado 2 vezes na $1^{\mathrm{a}}$ avaliação. Os descritores sugerem uma diminuição da dor através da TENS em pacientes com OA em joelhos, em 
meio as 3 avaliações efetuadas em cada paciente, houve uma diminuição na marcação dos descritores a medida que a terapia avançava.

$\mathrm{Na}$ escala analógica visual da dor, variando de 0 a $10 \mathrm{~cm}$, o valor de $\mathrm{p}=0,010$ podemos dizer que houve diferenças estatisticamente significativas nas amostras analisadas.

Em outras escala de avaliação, foi solicitado para o paciente marcar em uma linha o seu nível de dor variando de 0 a 10 . Neste caso, com o valor de $\mathrm{p}=0,272$ podemos dizer que não houve diferenças estatisticamente significativas nas amostras analisadas.

A estatística em relação ao questionário de avaliação funcional, os sintomas dos joelhos tratados, a pontuação variava em algumas questões de 1(menos grave) a 3 (mais grave) e em outras de 1 (menos grave) a 7 (mais grave). Na questão em que grau a dor em seu joelho afeta o seu nível de atividade diária, o valor de $\mathrm{p}=0,014$ em que podemos dizer que houve diferenças estatisticamente significativas nas amostras analisadas. Na questão que perguntava a que grau o rangido ou crepitação do seu joelho afeta o seu nível de atividade diária? $\mathrm{O}$ valor de $\mathrm{p}=0,082$ podemos dizer que não houve diferenças estatisticamente significativas nas amostras analisadas.

Na questão em que grau a rigidez no seu joelho afeta o seu nível de atividade diária, $\mathrm{o}$ valor de $\mathrm{p}=0,161$ podemos dizer que não houve diferenças estatisticamente significativas na amostra analisada.

Na questão, a que grau o aumento de volume no joelho afeta o seu nível de atividade diária, o valor de $\mathrm{p}=0,018$ podemos dizer que houve diferenças estatisticamente significativas nas amostras analisadas. 
Na questão em que grau o deslizamento do joelho afeta o seu nível de atividade diária, o valor de $\mathrm{p}=0,939$ podemos dizer que não houve diferenças estatisticamente significativas nas amostras analisadas.

Na questão em que se pergunta como o bloqueio do joelho afeta o nível de atividade diária, com o valor de $\mathrm{p}=0,327$ podemos dizer que não houve diferenças estatisticamente significativas nas amostras analisadas.

No item que perguntou em que grau a fraqueza ou falta de força de seu membro inferior afeta o seu nível de atividade diária, o valor ficou em $\mathrm{p}=0,174$, podemos dizer que não houve diferenças estatisticamente significativas nas amostras analisadas. Na pergunta como o seu joelho afeta sua capacidade de marcha, o valor de $\mathrm{p}=0,018$, podemos dizer que houve diferenças estatisticamente significativas nas amostras analisadas.

Na questão em que perguntava, por causa do seu joelho, você anda com muletas ou uma bengala, o teste não foi feito porque os valores de uma avaliação foram iguais ao outro.

Na pergunta: o seu joelho faz você mancar quando anda, com o valor de $p=0,472$ podemos dizer que não houve diferenças estatisticamente significativas nas amostras analisadas.

Na questão como o seu joelho afeta sua capacidade de subir escadas. O valor de $\mathrm{p}=0,247$, podemos dizer que não houve diferenças estatisticamente significativas nas amostras analisadas. 
No item em que perguntava como o seu joelho afeta sua capacidade de descer escadas, valor de $\mathrm{p}=0,039$, podemos dizer que houve diferenças estatisticamente significativas nas amostras analisadas.

$\mathrm{Na}$ pergunta como o seu joelho afeta a capacidade de ficar em pé, o valor de $\mathrm{p}=0,692$ podemos dizer que não houve diferenças estatisticamente significativas nas amostras analisadas. Na pergunta como o seu joelho afeta sua capacidade de se ajoelhar, o valor de $\mathrm{p}=0,819$ podemos dizer que não houve diferenças estatisticamente significativas nas amostras analisadas.

Na questão que perguntava como o seu joelho afeta a capacidade de agachar-se, o valor de $\mathrm{p}=0,174$, podemos dizer que não houve diferenças estatisticamente significativas nas amostras analisadas.

Na questão que perguntava como o seu joelho afeta a capacidade de sentar-se como o joelho dobrado, $\mathrm{o}$ valor de $\mathrm{p}=0,135$, podemos dizer que houve diferenças estatisticamente significativas.

No item em que perguntava como o seu joelho afeta sua capacidade de levantar-se de uma cadeira, o valor de $\mathrm{p}=0,039$, podemos dizer que houve diferenças estatisticamente significativas nas amostras analisadas. Na questão como você classificaria o seu nível atual da função do joelho durante as suas atividades diárias usuais em uma escala de 0 a 100, com 100 sendo o seu nível de função do joelho antes da sua lesão, o valor de p=0,309, podemos dizer que não houve diferenças estatisticamente significativas. Na questão como você classificaria a função global do seu joelho durante as suas atividades diárias usuais, o valor de $\mathrm{p}=0,006$, podemos dizer que houve diferenças estatisticamente significativas. 
Na questão, como resultado da lesão em seu joelho, como você classificaria o seu nível atual de atividade diária. $\mathrm{O}$ valor de $\mathrm{p}=0,008$, podemos dizer que houve diferenças estatisticamente significativas nas amostras analisadas.

No item em que perguntava: desde o inicio do tratamento o joelho, como você descreveria o seu progresso, o valor de $\mathrm{p}=0,022$ podemos dizer que houve diferenças estatisticamente significativas nas amostras analisadas.

No item que relacionava os níveis de atividade diária, em uma escala de 1 (normal) a 5 (mais grave). A questão que perguntava: antes da lesão de seu joelho, como você descreveria o seu nível usual de atividade, o valor de $\mathrm{p}=0,838$, podemos dizer que não houve diferenças estatisticamente significativas.

Na questão antes da cirurgia ou do tratamento de seu joelho, como você descreveria a sua atividade diária usual, o valor de $\mathrm{p}=0,779$ podemos dizer que não houve diferenças estatisticamente significativas. Na questão que perguntava como você descreveria o seu nível atual de atividade diária, o valor de $\mathrm{p}=0,444$ podemos dizer que não houve diferenças estatisticamente significativas.

$\mathrm{Na}$ avaliação feita antes e depois de cada sessão de fisioterapia a que foram submetidos. Os índices variaram de 0 a 10, com os seguintes resultados: a $1^{\mathrm{a}}$ sessão tanto as amostras de antes como depois tinham distribuição normal e então foi feito o teste " $t$ " de Student e verificamos que houve uma diminuição dos valores após a $1^{\mathrm{a}}$ sessão, com um valor de $\quad \mathrm{p}=0,023$ estatisticamente significativos. 
Resultados

Da $2^{\mathrm{a}}$ até a $10^{\mathrm{a}}$ sessão - tanto as amostras de antes como depois tinham distribuição não normal e então foi feito o teste de Wilcoxon. Em todas as sessões tivemos valores menores na sessão seguinte. Os valores de $\mathrm{p}$ mostram que as diferenças foram significativas conforme a tabela. 
Resultados

Tabela 1- como a sua dor muda com o tempo

\begin{tabular}{lrrrrrr} 
& \multicolumn{2}{c}{$1^{\text {a }}$ entrevista } & \multicolumn{2}{c}{$2^{\text {a }}$ entrevista } & \multicolumn{2}{c}{$3^{\text {a }}$ entrevista } \\
\hline Dor com o tempo & $\mathrm{N}$ & \multicolumn{1}{c}{$\%$} & $\mathrm{~N}$ & $\%$ & $\mathrm{~N}$ & $\%$ \\
Breve & 1 & 4,0 & 1 & 6,7 & 1 & 16,7 \\
Constante & 4 & 16,0 & 1 & 6,7 & & 0,0 \\
Contínua & 4 & 16,0 & 1 & 6,7 & 1 & 16,7 \\
Crescente & 1 & 4,0 & 1 & 6,7 & 1 & 16,7 \\
Intermitente & 4 & 16,0 & 2 & 13,3 & & 0,0 \\
Momentânea & 2 & 8,0 & 3 & 20,0 & 1 & 16,7 \\
Periódico-Momentânea & 4 & 16,0 & 4 & 26,7 & & 0,0 \\
Rítmica & & 0,0 & & 0,0 & 1 & 16,7 \\
Transitória & 5 & 20,0 & 2 & 13,3 & 1 & 16,7 \\
Total & 25 & 100,0 & 15 & 100,0 & 6 & 100,0 \\
\hline
\end{tabular}

Legenda: Variação da dor com o tempo nas 3 entrevista. 
Tabela 2 - Ao se avaliar o tipo da dor nas diferentes entrevistas tivemos a seguinte tabela:

\begin{tabular}{|c|c|c|c|c|c|c|}
\hline & \multicolumn{2}{|c|}{$1^{\mathrm{a}}$ entrevista } & \multicolumn{2}{|c|}{$2^{\mathrm{a}}$ entrevista } & \multicolumn{2}{|c|}{$3^{\mathrm{a}}$ entrevista } \\
\hline Tipo da dor & $\mathrm{N}$ & $\%$ & $\mathrm{~N}$ & $\%$ & $\mathrm{~N}$ & $\%$ \\
\hline Aborrecida & 4 & 2,2 & 6 & 7,1 & & 0,0 \\
\hline Adormece & 1 & 0,6 & 2 & 2,4 & 1 & 2,9 \\
\hline Agonizante & 2 & 1,1 & & 0,0 & & 0,0 \\
\hline Agulhada & 6 & 3,4 & 1 & 1,2 & 1 & 2,9 \\
\hline Amedrontadora & 3 & 1,7 & 1 & 1,2 & 1 & 2,9 \\
\hline Apavorante & 2 & 1,1 & & 0,0 & & 0,0 \\
\hline Aperta & 3 & 1,7 & 1 & 1,2 & & 0,0 \\
\hline Aperto & 3 & 1,7 & & 0,0 & & 0,0 \\
\hline Ardor & & 0,0 & 2 & 2,4 & & 0,0 \\
\hline Aterrorizante & 1 & 0,6 & & 0,0 & 1 & 2,9 \\
\hline Atormenta & 5 & 2,8 & 1 & 1,2 & 1 & 2,9 \\
\hline Atravessa & 1 & 0,6 & 1 & 1,2 & & 0,0 \\
\hline Beliscão & 2 & 1,1 & 4 & 4,8 & 1 & 2,9 \\
\hline Calor & 3 & 1,7 & 1 & 1,2 & & 0,0 \\
\hline Cansativa & 7 & 3,9 & 4 & 4,8 & 2 & 5,9 \\
\hline Castigante & 2 & 1,1 & 2 & 2,4 & & 0,0 \\
\hline Chata & 2 & 1,1 & & 0,0 & 1 & 2,9 \\
\hline Choque & 3 & 1,7 & 4 & 4,8 & 1 & 2,9 \\
\hline Coceira & 2 & 1,1 & 1 & 1,2 & 1 & 2,9 \\
\hline Como batida & 1 & 0,6 & 1 & 1,2 & & 0,0 \\
\hline Como pancada & 1 & 0,6 & & 0,0 & & 0,0 \\
\hline Cortante & 2 & 1,1 & 1 & 1,2 & & 0,0 \\
\hline Cruel & 2 & 1,1 & & 0,0 & & 0,0 \\
\hline Desgastante & & 0,0 & 2 & 2,4 & 1 & 2,9 \\
\hline Doída & 2 & 1,1 & 1 & 1,2 & 2 & 5,9 \\
\hline Dolorida & 6 & 3,4 & 2 & 2,4 & & 0,0 \\
\hline Em torção & 3 & 1,7 & & 0,0 & & 0,0 \\
\hline Enjoada & 6 & 3,4 & 4 & 4,8 & 2 & 5,9 \\
\hline Esmagamento & 3 & 1,7 & & 0,0 & & 0,0 \\
\hline Espalha & & 0,0 & & 0,0 & 1 & 2,9 \\
\hline Esticada & 2 & 1,1 & 2 & 2,4 & & 0,0 \\
\hline Estraçalha & 1 & 0,6 & & 0,0 & & 0,0 \\
\hline Exaustiva & 2 & 1,1 & & 0,0 & & 0,0 \\
\hline Facada & 2 & 1,1 & & 0,0 & & 0,0 \\
\hline Ferroada & 3 & 1,7 & 2 & 2,4 & 1 & 2,9 \\
\hline Fervente & 1 & 0,6 & & 0,0 & & 0,0 \\
\hline Fina & 5 & 2,8 & 5 & 6,0 & 3 & 8,8 \\
\hline Fisgada & 5 & 2,8 & 3 & 3,6 & 1 & 2,9 \\
\hline Formigamento & 6 & 3,4 & & 0,0 & 2 & 5,9 \\
\hline Forte & 4 & 2,2 & & 0,0 & & 0,0 \\
\hline Fria & 1 & 0,6 & 3 & 3,6 & & 0,0 \\
\hline Gelada & 2 & 1,1 & & 0,0 & 1 & 2,9 \\
\hline
\end{tabular}




\begin{tabular}{|c|c|c|c|c|c|c|}
\hline Insuportável & 3 & 1,7 & & 0,0 & & 0,0 \\
\hline Irradia & 3 & 1,7 & 2 & 2,4 & & 0,0 \\
\hline Latejante & 7 & 3,9 & 4 & 4,8 & 2 & 5,9 \\
\hline Machucada & 1 & 0,6 & & 0,0 & & 0,0 \\
\hline Mal localizada & 3 & 1,7 & 1 & 1,2 & & 0,0 \\
\hline Maldita & 1 & 0,6 & & 0,0 & & 0,0 \\
\hline Miserável & 3 & 1,7 & 1 & 1,2 & & 0,0 \\
\hline Mordida & & 0,0 & 1 & 1,2 & & 0,0 \\
\hline Pavorosa & 1 & 0,6 & & 0,0 & & 0,0 \\
\hline Penetra & 3 & 1,7 & 2 & 2,4 & & 0,0 \\
\hline Perfurante & 3 & 1,7 & 2 & 2,4 & 1 & 2,9 \\
\hline Pesada & 1 & 0,6 & 1 & 1,2 & & 0,0 \\
\hline Pontada & 6 & 3,4 & 3 & 3,6 & & 0,0 \\
\hline Punhalada & & 0,0 & 1 & 1,2 & & 0,0 \\
\hline Puxão & 1 & 0,6 & 1 & 1,2 & & 0,0 \\
\hline Que cega & & 0,0 & & 0,0 & 1 & 2,9 \\
\hline Que incomoda & 6 & 3,4 & 2 & 2,4 & 1 & 2,9 \\
\hline Queimação & 4 & 2,2 & 2 & 2,4 & 1 & 2,9 \\
\hline Rachando & 2 & 1,1 & & 0,0 & & 0,0 \\
\hline Repuxa & 5 & 2,8 & 1 & 1,2 & 1 & 2,9 \\
\hline Sensível & 4 & 2,2 & 3 & 3,6 & 2 & 5,9 \\
\hline Sufocante & 3 & 1,7 & & 0,0 & & 0,0 \\
\hline Tiro & 2 & 1,1 & & 0,0 & & 0,0 \\
\hline Torturante & 2 & 1,1 & & 0,0 & & 0,0 \\
\hline Tremor & 1 & 0,6 & & 0,0 & & 0,0 \\
\hline Vibração & 1 & 0,6 & & 0,0 & & 0,0 \\
\hline Total & 178 & 100,0 & 84 & 100,0 & 34 & 100,0 \\
\hline
\end{tabular}

Legenda: Avaliação do tipo de dor nas 3 entrevistas. 
Resultados

Tabela 3 - Que tipo de coisas alivia sua dor?

2. Que tipo de coisas alivia sua dor?

\begin{tabular}{|c|c|c|c|}
\hline $\begin{array}{c}\text { paciente } \\
n^{\circ}\end{array}$ & $1^{\mathrm{a}}$ entrevista & $2^{\mathrm{a}}$ entrevista & $3^{a}$ entrevista \\
\hline 1 & somente medicação & $\begin{array}{l}\text { a terapia foi relatada } \\
\text { como condição que } \\
\text { alivia. }\end{array}$ & \\
\hline 2 & Repouso & Repouso & sem dor \\
\hline 3 & $\begin{array}{l}\text { Medicação, repouso, } \\
\text { massagem }\end{array}$ & Remédio, repouso & $\begin{array}{l}\text { A terapia com a } \\
\text { TENS }\end{array}$ \\
\hline 4 & Medicação & Repouso & $\begin{array}{l}\text { Repouso, posição } \\
\text { sentada }\end{array}$ \\
\hline 5 & & Quando está sentada & Repouso \\
\hline 6 & Medicação & Medicação & $\begin{array}{l}\text { Somente com } \\
\text { remédio }\end{array}$ \\
\hline 7 & & marchar e descansar & sem queixas de dor \\
\hline 8 & $\begin{array}{l}\text { Deambulação de } \\
\text { forma lenta alivia a } \\
\text { dor }\end{array}$ & Repouso & $\begin{array}{l}\text { Caminhar alivia a } \\
\text { dor, alongamento }\end{array}$ \\
\hline $\begin{array}{r}9 \\
10\end{array}$ & $\begin{array}{l}\text { Somente medicação } \\
\text { medicação }\end{array}$ & A terapia com a TENS & \\
\hline
\end{tabular}

Tabela3.1

3. Que tipo de coisas aumenta sua dor?

\begin{tabular}{|c|c|c|c|}
\hline $\begin{array}{c}\text { paciente } \\
n^{\circ}\end{array}$ & $1^{\mathrm{a}}$ entrevista & $2^{a}$ entrevista & $3^{\mathrm{a}}$ entrevista \\
\hline 1 & $\begin{array}{l}\text { marchar muito, } \\
\text { descer escadas }\end{array}$ & Atividades domésticas & \\
\hline 2 & $\begin{array}{l}\text { Marchar, ficar em pé, } \\
\text { ajoelhar }\end{array}$ & $\begin{array}{l}\text { andar muito, ajoelhar, } \\
\text { ficar em pé }\end{array}$ & sem queixas \\
\hline 3 & postura bípede & muita movimentação & $\begin{array}{l}\text { Muita } \\
\text { movimentação }\end{array}$ \\
\hline 4 & Marchar & Frio, muito movimento & Muito movimento \\
\hline 5 & & Muito tempo em pé. & $\begin{array}{l}\text { andar depressa, subir } \\
\text { ladeiras }\end{array}$ \\
\hline 6 & Marcha & Marcha & Baixa temperatura \\
\hline 7 & & $\begin{array}{l}\text { ficar em pé por muito } \\
\text { tempo }\end{array}$ & sem queixa de dor \\
\hline 8 & $\begin{array}{l}\text { Período longo em pé, } \\
\text { subir e descer escadas }\end{array}$ & $\begin{array}{l}\text { ficar em uma mesma } \\
\text { posição muito tempo }\end{array}$ & $\begin{array}{l}\text { muito tempo } \\
\text { sentado, ou em pé. }\end{array}$ \\
\hline 9 & Marcha & $\begin{array}{l}\text { Quando sobe e desce } \\
\text { rampa }\end{array}$ & \\
\hline
\end{tabular}


10 subir e descer

escadas, aos esforços,

agachamento.

A seguir são analisadas as questões apresentadas no questionário:

Inteligência do paciente: 1(baixa) $2 \quad 3 \quad 4 \quad 5$ (alta)

Tabela 4 - Avaliação da inteligência do paciente para aplicação do questionário

Ranks

\begin{tabular}{lrr}
\multicolumn{2}{c}{ Ranks } & \\
\hline & Mean Rank & \\
Inteligência & & 1,86 \\
inteligencia2 & & 2,07 \\
inteligencia3 & 2,07
\end{tabular}

Test Statistics(a)

$\mathrm{N}$

Chi-Square 2,000

Df

Asymp. Sig.

a. Friedman Test

0,368

Legenda: Neste caso, com o valor de $\mathrm{p}=0,368$ podemos dizer que não houve diferenças estatisticamente significativas nas amostras analisadas.

Na parte 4 do questionário “Quão forte é a sua dor?” era oferecida uma escala, variando de 1 a 5 conforme o esquema:

Tabela 5 - Avaliação de quão forte é a sua dor

1-Leve 2-Incômoda 3-Angustiante 4-Horrível 5-Excruciante 
Resultados

A seguir analisamos cada uma das questões seguintes:

1.Qual palavra descreve a sua dor exatamente neste momento?

Tabela 6 - Dor exatamente neste momento

\begin{tabular}{lrr}
\hline \multicolumn{1}{c}{ Ranks } \\
\hline No momento & Mean Rank r \\
No momento 2 & & 2,25 \\
No momento 3 & 1,75 \\
& & 2,00 \\
N & & \\
Chi-Square & Test Statistics(a) & 6 \\
Df & & 1,200 \\
Asymp. Sig. & & 2 \\
& & 0,549
\end{tabular}

a. Friedman Test

Legenda: Neste caso, com o valor de $\mathrm{p}=0,549$ podemos dizer que não houve diferenças estatisticamente significativas nas amostras analisadas. 
2. Qual palavra a descreve no pior momento?

Tabela 7 - Palavra no pior momento

\section{Ranks}

\section{Mean Rank}

Pior momento

Pior momento 2

Pior momento 3

Test Statistics(a)

$\mathrm{N}$

Chi-Square

Df

Asymp. Sig.

0,104

a. Friedman Test

Legenda: Neste caso, com o valor de $\mathrm{p}=0,104$ podemos dizer que não houve diferenças estatisticamente significativas nas amostras analisadas.

3. Qual palavra descreve a pior dor de dente que você já sentiu?

Tabela 8 - Pior dor de dente que você sentiu

Ranks

Mean Rank

Dor de dente

Dor de dente2

Dor de dente3

Test Statistics(a)

$\mathrm{N}$

Chi-Square

Df

Asymp. Sig.

a. Friedman Test

Legenda: Neste caso, com o valor de $\mathrm{p}=0,504$ podemos dizer que não houve diferenças estatisticamente 
4. Qual palavra descreve a pior dor de cabeça que você já sentiu?

Tabela 9 - Pior dor de cabeça que você sentiu

Ranks

\begin{tabular}{|c|c|c|}
\hline \multicolumn{3}{|c|}{ Mean Rank } \\
\hline Dor de cabeça & & 1,79 \\
\hline Dor de cabeça 2 & & 2,07 \\
\hline Dor de cabeça 3 & & 2,14 \\
\hline \multicolumn{3}{|c|}{ Test Statistics(a) } \\
\hline $\mathrm{N}$ & & 7 \\
\hline Chi-Square & & 0,778 \\
\hline Df & & 2 \\
\hline $\begin{array}{l}\text { Asymp. Sig. } \\
\text { a. Friedman Test }\end{array}$ & & 0,678 \\
\hline
\end{tabular}

Legenda: Neste caso, com o valor de $\mathrm{p}=0,678$ podemos dizer que não houve diferenças estatisticamente significativas nas amostras analisadas.

5. Qual palavra descreve a pior dor de estômago que você já sentiu?

Tabela 10 - Pior dor de estômago que você sentiu

Ranks

\section{Mean Rank}

Dor estomago

Dor estomago 2

Dor estomago 3

Test Statistics(a)

$\mathrm{N}$

Chi-Square

Df

Asymp. Sig.

a. Friedman Test

Legenda: Neste caso, com o valor de $\mathrm{p}=0,951$ podemos dizer que não houve diferenças estatisticamente significativas 
No Questionário de Dor de McGill foram avaliados os seguintes descritores:

Número de descritores escolhidos: Sensitivos

Tabela 11 - Descritores sensitivos

Ranks

\begin{tabular}{lrr}
\hline & Mean Rank & \\
Sensitivos & & 3,00 \\
Sensitivos 2 & 1,89 \\
Sensitivos 3 & 1,11
\end{tabular}

Test Statistics(a)

$\mathrm{N}$

Chi-Square

Df 16,222

Asymp. Sig. 2

a. Friedman Test

0,000

Legenda: Neste caso, com o valor de $\mathrm{p}<0,0001$ podemos dizer que houve diferenças estatisticamente significativas nas amostras analisadas.

Número de descritores escolhidos: Afetivos

Tabela 12 - Descritores afetivos

Ranks

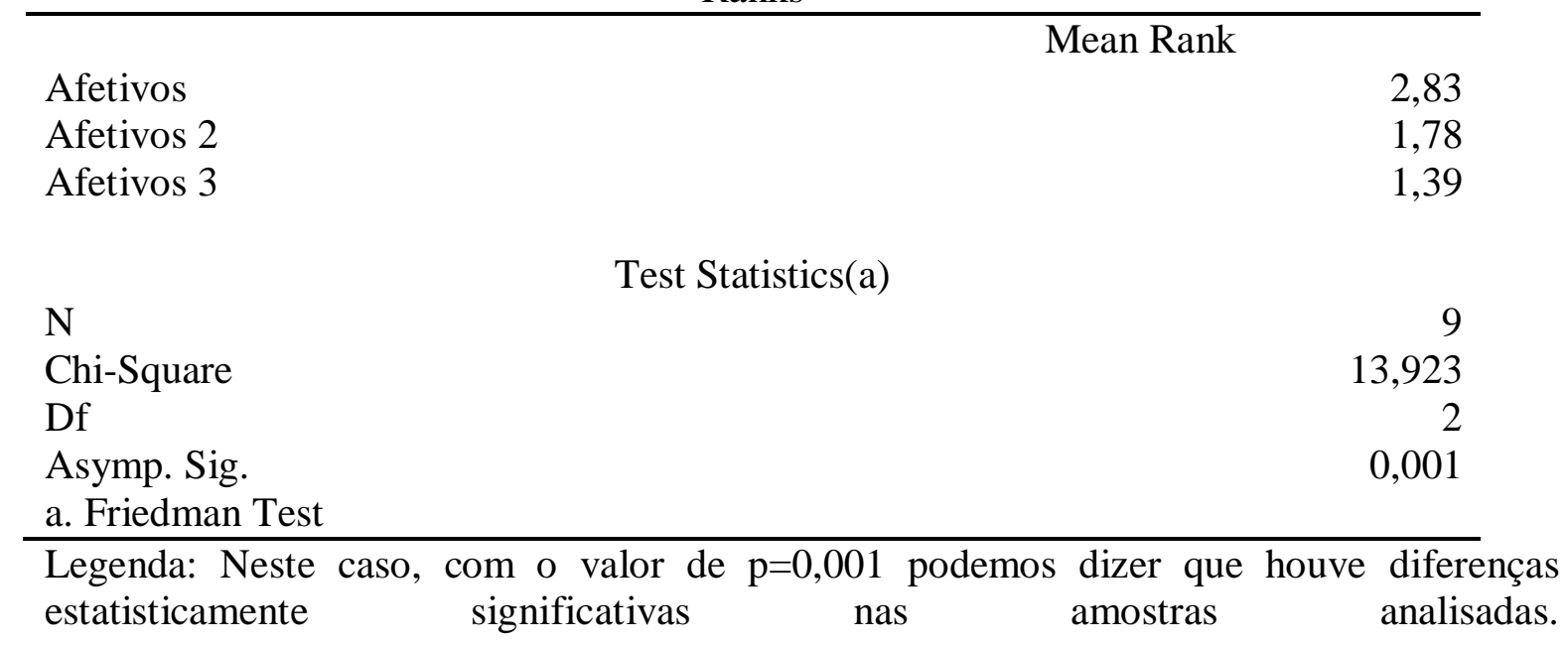


Resultados

Número de descritores escolhidos: Avaliativos

Tabela 13 - Descritores avaliativos

Ranks

\section{Mean Rank}

Avaliativas

Avaliativas 2

2,78

Avaliativas 3

Test Statistics(a)

$\mathrm{N}$

Chi-Square

Df

Asymp. Sig.

0,001

a. Friedman Test

Legenda: Neste caso, com o valor de $\mathrm{p}=0,001$ podemos dizer que houve diferenças estatisticamente significativas nas amostras analisadas.

Número de descritores escolhidos: Miscelânea

Tabela 14 - Descritores miscelânea

Ranks

Mista

Mean Rank

Mista 2

2,67

Mista 3

Test Statistics(a)

$\mathrm{N}$

Chi-Square

9,000

Df

2

Asymp. Sig.

0,011

a. Friedman Test

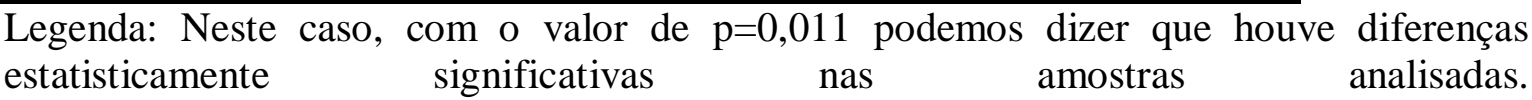
nas 
Número de descritores escolhidos: Total

Tabela 15 - Descritores quantidade total

Ranks

\begin{tabular}{lrr}
\hline & Mean Rank & \\
Total de descritores & 3,00 \\
Total descritores 2 & 1,89 \\
Total descritores 3 & 1,11
\end{tabular}

Test Statistics(a)

$\mathrm{N}$

Chi-Square

Asymp. Sig.

0,000

a. Friedman Test

Legenda: Neste caso, com o valor de $\mathrm{p}<0,0001$ podemos dizer que houve diferenças estatisticamente significativas nas amostras analisadas.

Índice de dor: Sensitivo

Tabela 16 - Índice de dor sensitivo

Ranks

Índice de dor sensitivo

Mean Rank

Índice de dor sensitivo 2

Índice de dor sensitivo 3

1,11

Test Statistics(a)

$\mathrm{N}$

Chi-Square

16,000

Df

2

Asymp. Sig.

0,000

a. Friedman Test

Legenda: Neste caso, com o valor de $\mathrm{p}<0,0001$ podemos dizer que houve diferenças estatisticamente significativas nas amostras analisadas. 
Índice de dor: Afetivo

Tabela 17 - Índice de dor afetivo

Ranks

Índice de dor afetivo

Mean Rank

Índice de dor afetivo 2

Índice de dor afetivo 3

Test Statistics(a)

$\mathrm{N}$

Chi-Square

Df

Asymp. Sig.

0,001

a. Friedman Test

Legenda: Neste caso, com o valor de $\mathrm{p}=0,001$ podemos dizer que houve diferenças estatisticamente significativas nas amostras analisadas.

Índice de dor: Avaliativo

Tabela 18 - Índice de dor avaliativo

Ranks

Índice de dor avaliativo

Mean Rank

Índice de dor avaliativo 2

2,61

Índice de dor avaliativo 3

1,78

1,61

Test Statistics(a)

$\mathrm{N}$

Chi-Square

Df

Asymp. Sig.

a. Friedman Test

0,006

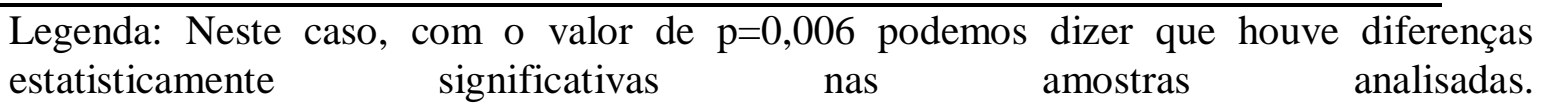


Índice de dor: Miscelânea

Tabela 19 - Indice dor miscelânea

Ranks

\section{Mean Rank}

Índice de dor miscelânea

Índice de dor miscelânea 2

Índice de dor miscelânea 3

Test Statistics(a)

$\mathrm{N}$

Chi-Square

Df

Asymp. Sig.

0,002

a. Friedman Test

Legenda: Neste caso, com o valor de $\mathrm{p}=0,002$ podemos dizer que houve diferenças estatisticamente significativas nas amostras analisadas.

Índice de dor: Total

Tabela 20 - Índice de dor total

Ranks

Índice de dor total

Mean Rank

Índice de dor total 2

Índice de dor total 3

Test Statistics(a)

$\mathrm{N}$

Chi-Square

Df

Asymp. Sig.

a. Friedman Test

Legenda: Neste caso, com o valor de $\mathrm{p}<0,0001$ podemos dizer que houve diferenças estatisticamente significativas nas analisadas. 
$\mathrm{Na}$ Escala Analógica visual da dor, variando de 0 a $10 \mathrm{~cm}$. Tivemos os seguintes resultados:

Tabela 21 - Escala analógica visual da dor, variando de 0 a $10 \mathrm{~cm}$

Ranks

Escala de dor

Mean Rank

Escala de dor 2

2,78

Escala de dor 3

1,78

1,44

Test Statistics(a)

$\mathrm{N}$

Chi-Square

9,176

Df

Asymp. Sig.

0,010

a. Friedman Test

Legenda: Neste caso, com o valor de $\mathrm{p}=0,010$ podemos dizer que houve diferenças estatisticamente significativas nas amostras analisadas.

Na questão seguinte, se pedia ao paciente para marcar em uma linha o seu "nível de dor", variando de 0 a 10.

Tabela 22 - Marcação em uma linha, solicitando o seu nível de dor, variando de 0 a 10

Ranks

Nível de dor

Nível de dor 2

Nível de dor 3

Test Statistics(a)

$\mathrm{N}$

Chi-Square

Df 2,606

Asymp. Sig.

a. Friedman Test

0,272

Legenda: Neste caso, com o valor de $\mathrm{p}=0,272$ podemos dizer que não houve diferenças estatisticamente significativas nas amostras analisadas. 
Resultados

Nas questões seguintes, sobre os sintomas dos joelhos, a pontuação variava em algumas questões de 1 (menos grave) a 3 (mais grave) e em outras de 1 (menos grave) a 7 (mais grave).

1. Em que grau a dor em seu joelho afeta o seu nível de atividade diária?

Tabela 23 - Em que grau a dor em seu joelho afeta o seu nível de atividade diária Ranks Mean Rank

Dor joelho 2,57

Dor joelho 2

2,07

Dor joelho 3

1,36

Test Statistics(a)

$\mathrm{N}$

Chi-Square

Df

Asymp. Sig.

a. Friedman Test

0,014

Legenda: Neste caso, com o valor de $\mathrm{p}=0,014$ podemos dizer que houve diferenças
estatisticamente significativas nas amostras analisadas. 
2. A que grau o rangido ou crepitação do seu joelho afeta o seu nível de atividade diária?

Tabela 24 - A que grau o rangido ou crepitação do seu joelho afeta o seu nível de atividade diária

Ranks

\begin{tabular}{|c|c|c|}
\hline & Mean Rank & \\
\hline $\begin{array}{l}\text { Rangido ou } \\
\text { crepitação }\end{array}$ & & 2,42 \\
\hline $\begin{array}{l}\text { Rangido ou } \\
\text { crepitação2 }\end{array}$ & & 2,00 \\
\hline $\begin{array}{l}\text { Rangido ou } \\
\text { crepitacao3 }\end{array}$ & & 1,58 \\
\hline \multicolumn{3}{|c|}{ Test Statistics(a) } \\
\hline $\mathrm{N}$ & & 6 \\
\hline Chi-Square & & 5,000 \\
\hline Df & & 2 \\
\hline $\begin{array}{l}\text { Asymp. Sig. } \\
\text { a. Friedman Test }\end{array}$ & & 0,082 \\
\hline
\end{tabular}

Legenda: Neste caso, com o valor de $\mathrm{p}=0,082$ podemos dizer que não houve diferenças estatisticamente significativas nas amostras analisadas.

3. Em que grau a rigidez no seu joelho afeta o seu nível de atividade diária?

Tabela 25 - Em que grau a rigidez no seu joelho afeta o seu nível de atividade diária

Ranks

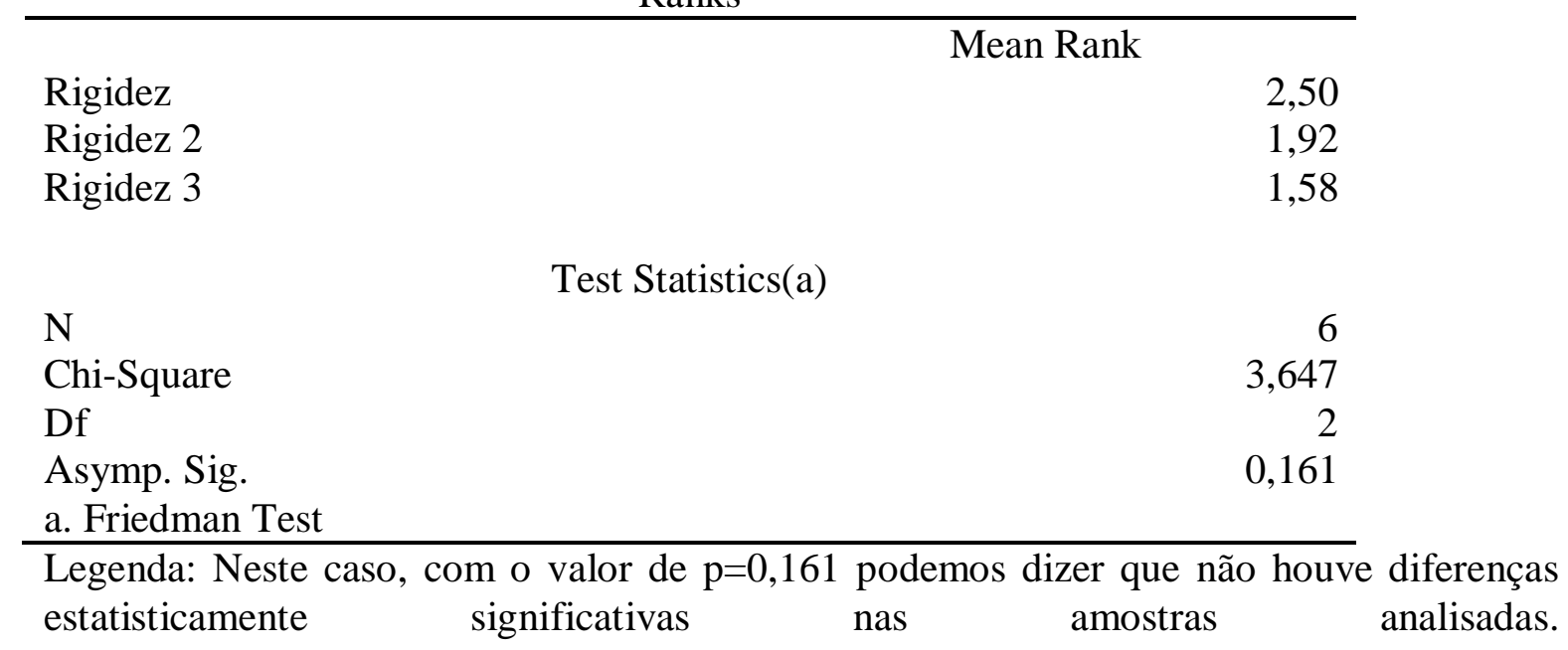


Resultados

4. A que grau o aumento de volume no joelho afeta o seu nível de atividade diária?

Tabela 26 - A que grau o aumento de volume no joelho afeta o seu nível de atividade diária Ranks

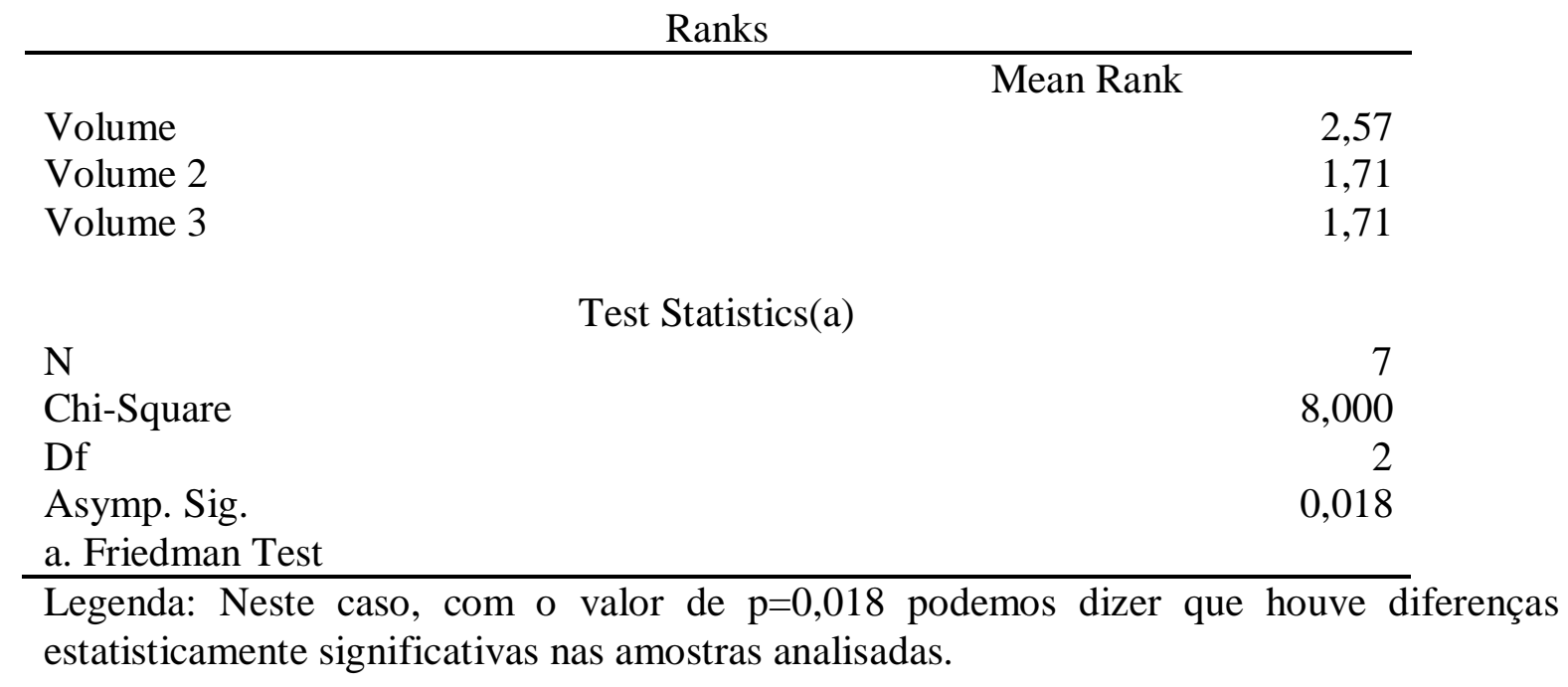

5. Em que grau o deslizamento do joelho afeta o seu nível de atividade diária?

Tabela 27 - Em que grau o deslizamento do joelho afeta o seu nível de atividade diária

Ranks

\begin{tabular}{lr}
\hline & Mean Rank \\
Deslizamento & 2,08 \\
Deslizamento 2 & 1,92 \\
Deslizamento 3 & 2,00 \\
& \\
N & \\
Chi-Square & \\
Df & 6,125 \\
Asymp. Sig. & 2 \\
a. Friedman Test & 0,939 \\
\hline
\end{tabular}

Legenda: Neste caso, com o valor de $\mathrm{p}=0,939$ podemos dizer que não houve diferenças estatisticamente significativas nas amostras analisadas. 
6. Em que grau o bloqueio do seu joelho afeta o seu nível de atividade diária?

Tabela 28 - Em que grau o bloqueio do seu joelho afeta o seu nível de atividade diária

Ranks

\begin{tabular}{lrr}
\hline & Mean Rank r \\
Bloqueio & & 2,42 \\
Bloqueio 2 & & 1,75 \\
Bloqueio 3 & 1,83 \\
& & \\
N & Test Statistics(a) & 6 \\
Chi-Square & 2,235 \\
Df & 2 \\
Asymp. Sig. & 0,327 \\
a. Friedman Test & \\
\hline
\end{tabular}

Legenda: Neste caso, com o valor de $\mathrm{p}=0,327$ podemos dizer que não houve diferenças estatisticamente significativas nas amostras analisadas.

7. Em que grau a fraqueza ou falta de força de seu membro inferior afeta o seu nível de atividade diária?

Tabela 29 - Em que grau a fraqueza ou falta de força de seu membro inferior afeta o seu nível de atividade diária

Ranks

Fraqueza

Mean Rank

Fraqueza 2

2,43

Fraqueza 3

1,86

1,71

Test Statistics(a)

$\mathrm{N}$

Chi-Square

Df

Asymp. Sig.

0,174

a. Friedman Test

Legenda: Neste caso, com o valor de $\mathrm{p}=0,174$ podemos dizer que não houve diferenças estatisticamente significativas nas amostras analisadas. 
Resultados

8. Como o seu joelho afeta sua capacidade de marcha?

Tabela 30 - Como o seu joelho afeta sua capacidade de marcha

Ranks

\begin{tabular}{lll}
\hline & Mean Rank & \\
Marcha & & 2,57 \\
Marcha 2 & 2,00 \\
Marcha 3 & 1,43
\end{tabular}

Test Statistics(a)

$\mathrm{N}$

Chi-Square

8,000

Df

Asymp. Sig. 0,018

a. Friedman Test

Legenda: Neste caso, com o valor de $\mathrm{p}=0,018$ podemos dizer que houve diferenças estatisticamente significativas nas amostras analisadas.

9.Por causa do seu joelho, você anda com muletas ou uma bengala?

Tabela 31 - Por causa do seu joelho, você anda com muletas ou uma bengala

Ranks

Bengala

Bengala 2

2,00

Mean Rank

Bengala 3

2,00

2,00

Test Statistics(a)

$\mathrm{N}$

Chi-Square

Df

Asymp. Sig.

a. Friedman Test

Legenda: Nesta questão o teste não foi feito porque os valores de uma avaliação foram iguais ao outro. 
Resultados

10. O seu joelho faz você mancar quando anda?

Tabela 32 - O seu joelho faz você mancar quando anda

Ranks

\begin{tabular}{|c|c|c|}
\hline & & \\
\hline Mancar & & 2,21 \\
\hline Mancar 2 & & 2,00 \\
\hline Mancar 3 & & 1,79 \\
\hline \multicolumn{3}{|c|}{ Test Statistics(a) } \\
\hline $\mathrm{N}$ & & 7 \\
\hline Chi-Square & & 1,500 \\
\hline Df & & 2 \\
\hline Asymp. Sig. & & 0,472 \\
\hline
\end{tabular}

Legenda: Neste caso, com o valor de $\mathrm{p}=0,472$ podemos dizer que não houve diferenças estatisticamente significativas nas amostras analisadas.

11. Como o seu joelho afeta sua capacidade de subir escadas?

Tabela 33 - Como o seu joelho afeta sua capacidade de subir escadas

Ranks

Subir escada

Mean Rank

Subir escada 2

2,36

Subir escada 3

1,93

1,71

Test Statistics(a)

$\mathrm{N}$

Chi-Square

Df

Asymp. Sig.

a. Friedman Test

0,247

Legenda: Neste caso, com o valor de $\mathrm{p}=0,247$ podemos dizer que não houve diferenças estatisticamente

significativas nas amostras analisadas. 
Resultados

12. Como o seu joelho afeta sua capacidade de descer escadas?

Tabela 34 - Como o seu joelho afeta sua capacidade de descer escadas

Ranks

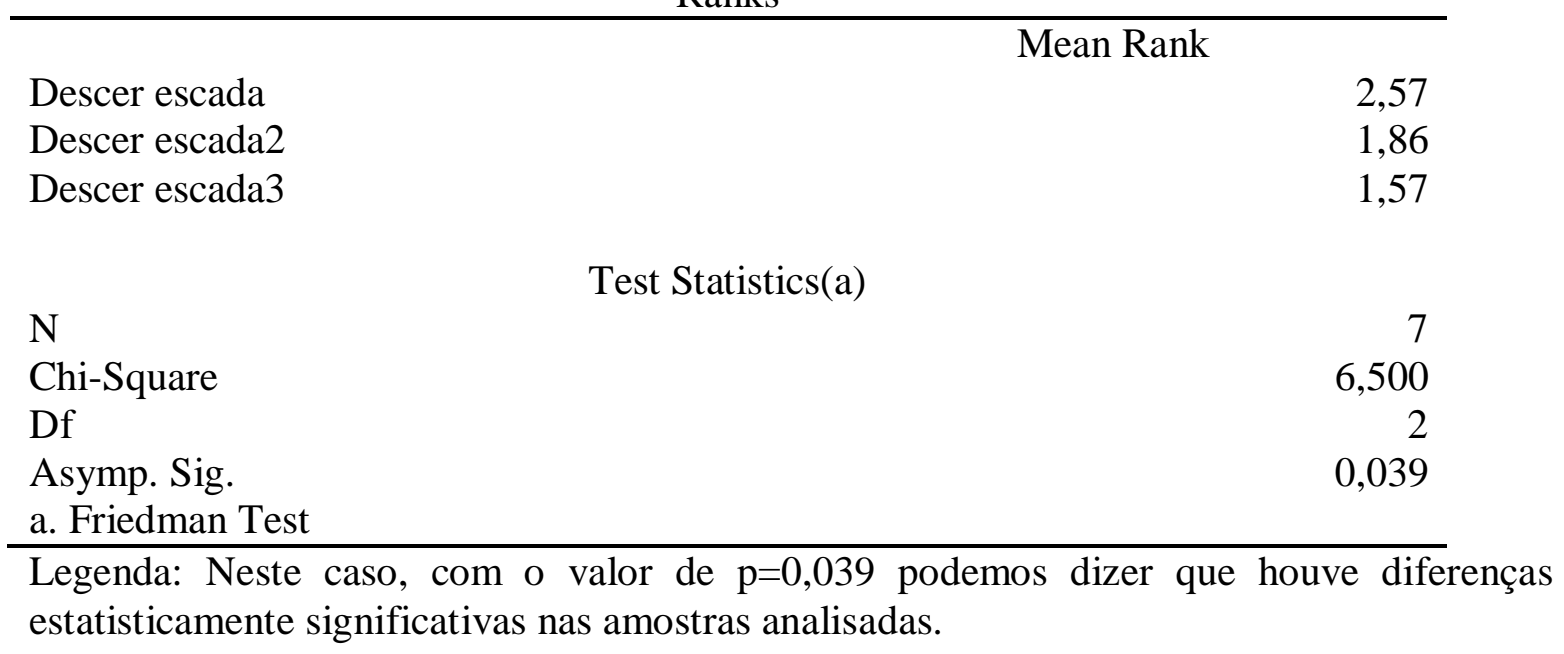

13. Como o seu joelho afeta a capacidade de ficar em pé?

Tabela 35 - Como o seu joelho afeta a capacidade de ficar em pé

Ranks

Ficar em pé

2,21

Ficar em pé 2

1,93

Ficar em pé 3

Test Statistics(a)

$\mathrm{N}$

Chi-Square

0,737

Df

Asymp. Sig.

0,692

a. Friedman Test

Legenda: Neste caso, com o valor de $\mathrm{p}=0,692$ podemos dizer que não houve diferenças estatisticamente significativas

nas amostras analisadas. 
Resultados

14. Como o seu joelho afeta sua capacidade de se ajoelhar?

Tabela 36 - Como o seu joelho afeta sua capacidade de se ajoelhar

Ranks

\begin{tabular}{|c|c|c|}
\hline & & \\
\hline Ajoelhar & & 2,07 \\
\hline Ajoelhar 2 & & 2,07 \\
\hline Ajoelhar 3 & & 1,86 \\
\hline \multicolumn{3}{|c|}{ Test Statistics(a) } \\
\hline $\mathrm{N}$ & & 7 \\
\hline Chi-Square & & 0,400 \\
\hline Df & & 2 \\
\hline $\begin{array}{l}\text { Asymp. Sig. } \\
\text { a. Friedman Test }\end{array}$ & & 0,819 \\
\hline
\end{tabular}

15. Como o seu joelho afeta a capacidade de agachar-se?

Tabela 37 - Como o seu joelho afeta a capacidade de agachar-se

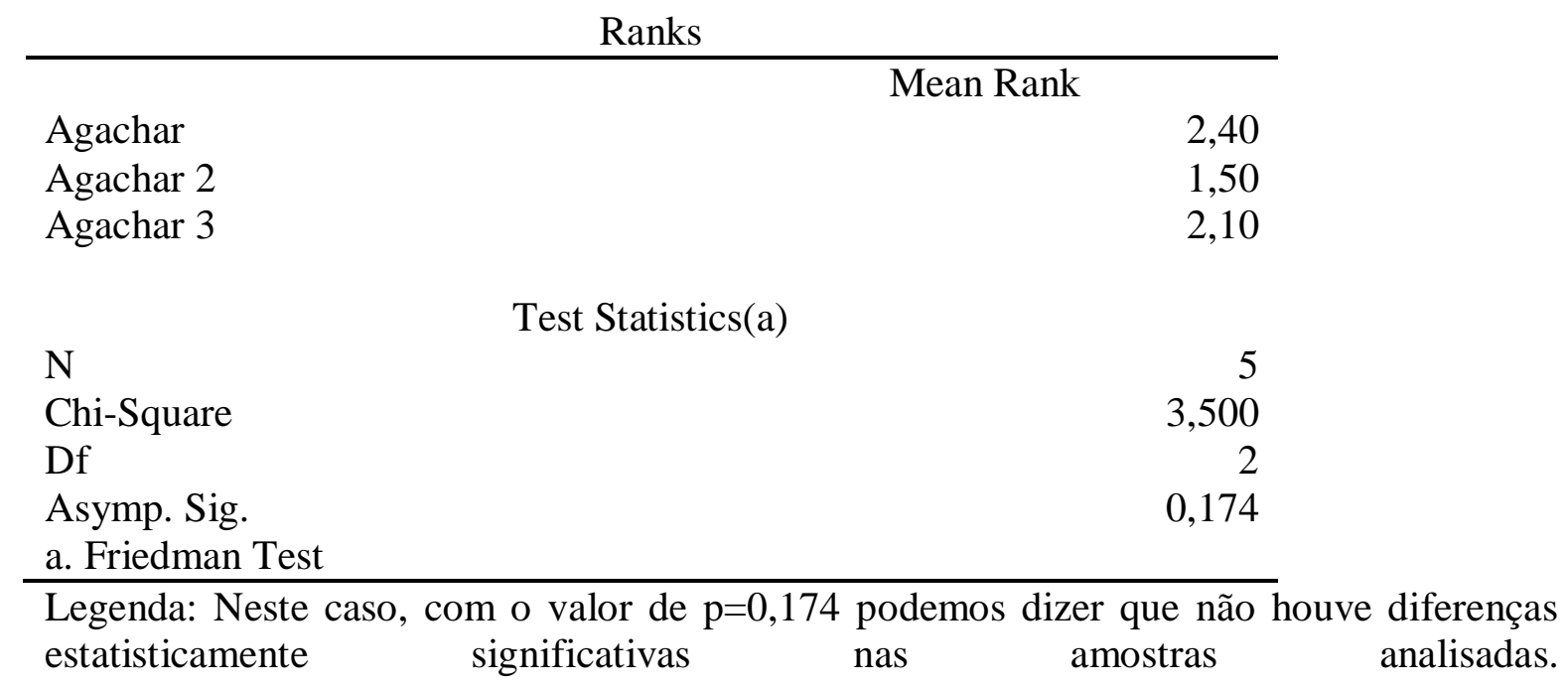


16. Como o seu joelho afeta a capacidade sentar-se com o joelho dobrado?

Tabela 38 - Como o seu joelho afeta a capacidade sentar-se com o joelho dobrado

Ranks

\begin{tabular}{|c|c|c|}
\hline \multicolumn{3}{|c|}{ Mean Rank } \\
\hline Joelho dobrado & & 2,43 \\
\hline Joelho dobrado 2 & & 1,57 \\
\hline Joelho dobrado 3 & & 2,00 \\
\hline \multicolumn{3}{|c|}{ Test Statistics(a) } \\
\hline $\mathrm{N}$ & & 7 \\
\hline Chi-Square & & 4,000 \\
\hline Df & & 2 \\
\hline $\begin{array}{l}\text { Asymp. Sig. } \\
\text { a. Friedman Test }\end{array}$ & & 0,135 \\
\hline
\end{tabular}

Legenda: Neste caso, com o valor de $\mathrm{p}=0,135$ podemos dizer que não houve diferenças estatisticamente significativas nas amostras analisadas.

17. Como o seu joelho afeta sua capacidade de levantar-se de uma cadeira?

Tabela 39 - Como o seu joelho afeta sua capacidade de levantar-se de uma cadeira

Ranks

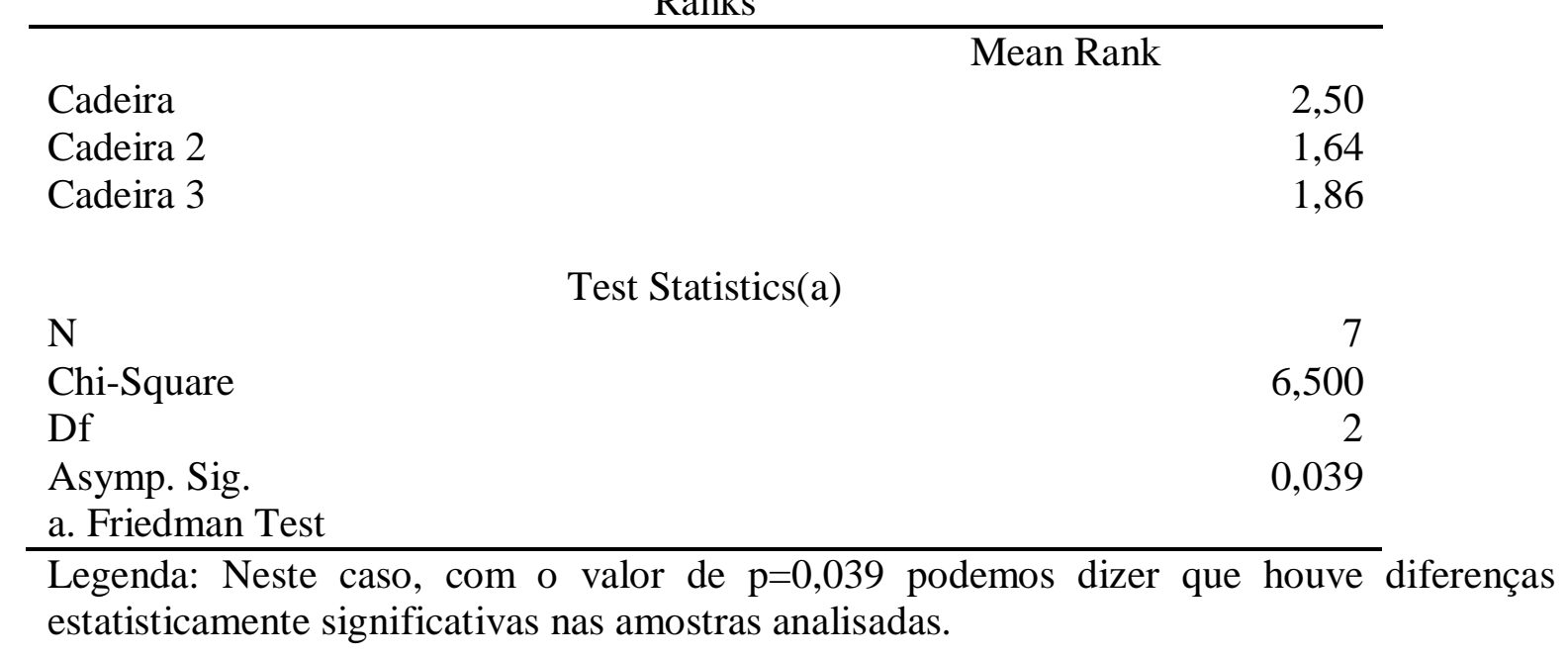


18. Como você classificaria o seu nível atual da função do joelho durante as suas atividades diárias usuais em uma escala de 0 a 100, com 100 sendo o seu nível de função do joelho antes da sua lesão?

Tabela 40 - Como você classificaria o seu nível atual da função do joelho durante as suas atividades diárias usuais em uma escala de 0 a 100, com 100 sendo o seu nível de função do joelho antes da sua lesão

\begin{tabular}{|c|c|c|}
\hline \multicolumn{3}{|c|}{ Ranks } \\
\hline & & \\
\hline Função joelho & & 1,57 \\
\hline Função joelho 2 & & 2,21 \\
\hline Função joelho 3 & & 2,21 \\
\hline \multicolumn{3}{|c|}{ Test Statistics(a) } \\
\hline $\mathrm{N}$ & & 7 \\
\hline Chi-Square & & 2,348 \\
\hline Df & & 2 \\
\hline $\begin{array}{l}\text { Asymp. Sig. } \\
\text { a. Friedman Test }\end{array}$ & & 0,309 \\
\hline
\end{tabular}

Legenda: Neste caso, com o valor de $\mathrm{p}=0,309$ podemos dizer que não houve diferenças estatisticamente significativas nas amostras analisadas. 
Resultados

19. Como você classificaria a função global do seu joelho durante as suas atividades diárias usuais?

Tabela 41 - Como você classificaria a função global do seu joelho durante as suas atividades diárias usuais

\section{Ranks}

Função global

Função global 2

2,79

Mean Rank

Função global 3

1,86

1,36

Test Statistics(a)

$\mathrm{N}$

Chi-Square

Df 10,300

Asymp. Sig.

a. Friedman Test

0,006

Legenda: Neste caso, com o valor de $\mathrm{p}=0,006$ podemos dizer que houve diferenças estatisticamente significativas nas amostras analisadas. 
20. Como resultado da lesão em seu joelho, como você classificaria o seu nível atual de atividade diária?

Tabela 42 - Como resultado da lesão em seu joelho, como você classificaria o seu nível atual de atividade diária

Ranks

Nível atual

Mean Rank

Nível atual 2

Nível atual 3

Test Statistics(a)

$\mathrm{N}$

Chi-Square

Df

Asymp. Sig.

0,008

a. Friedman Test

Legenda: Neste caso, com o valor de $\mathrm{p}=0,008$ podemos dizer que houve diferenças estatisticamente significativas nas amostras analisadas.

21. Desde o início do tratamento do joelho, como você descreveria o seu progresso?

Tabela 43 - Desde o início do tratamento do joelho, como você descreveria o seu progresso

Ranks

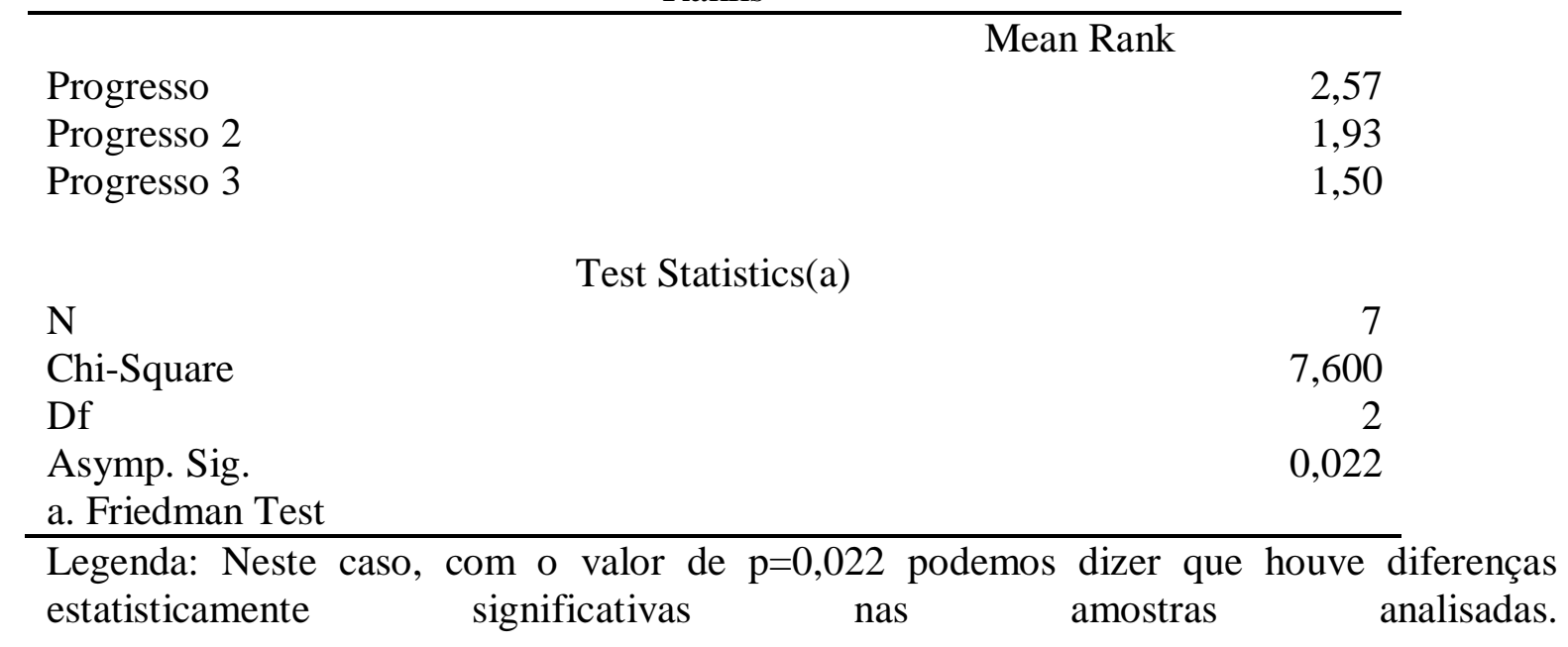


Resultados

Em relação aos níveis de atividade diária, em uma escala de 1 (normal) a 5 (mais grave), tivemos os seguintes resultados:

Antes da lesão de seu joelho, como você descreveria o seu nível usual de atividade?

Tabela 44 - Antes da lesão de seu joelho, como você descreveria o seu nível usual de atividade

Ranks

Antes da lesão

Antes da lesão 2

Antes da lesão 3

Test Statistics(a)

$\mathrm{N}$

\section{Mean Rank}

\section{1,92 \\ 1,92 \\ , 17}

Chi-Square

Df

Asymp. Sig.

0,838

a. Friedman Test

Legenda: Neste caso, com o valor de $\mathrm{p}=0,838$ podemos dizer que não houve diferenças estatisticamente significativas nas amostras analisadas. 
Antes da cirurgia ou do tratamento de seu joelho, como você descreveria a sua atividade diária usual?

Tabela 45 - Antes da cirurgia ou do tratamento de seu joelho, como você descreveria a sua atividade diária usual

Ranks

\begin{tabular}{lr}
\hline & Mean Rank \\
Antes da cirurgia ou tratamento & 2,17 \\
Antes da cirurgia ou tratamento 2 & 1,92 \\
Antes da cirurgia ou tratamento 3 & 1,92 \\
& Test Statistics(a) \\
N & \\
Chi-Square & 6 \\
Df & 0,500 \\
Asymp. Sig. & 2 \\
a. Friedman Test & 0,779 \\
\hline
\end{tabular}

Legenda: Neste caso, com o valor de $\mathrm{p}=0,779$ podemos dizer que não houve diferenças estatisticamente significativas nas amostras analisadas.

Como você descreveria o seu nível atual de atividade diária?

Tabela 46 - Como você descreveria o seu nível atual de atividade diária

Ranks

Mean Rank

Nível atividade diária

Nível atividade diária 2

2,10

Nível atividade diária 3

Test Statistics(a)

$\mathrm{N}$

Chi-Square

Df

Asymp. Sig.

a. Friedman Test

Legenda: Neste caso, com o valor de $\mathrm{p}=0,444$ podemos dizer que não houve diferenças estatisticamente significativas nas amostras analisadas. 
Para cada paciente foi feita uma avaliação antes e depois de cada uma das dez sessões de fisioterapia a que foram submetidos. Os índices variaram de 0 a 10 , com os seguintes resultados comparativos:

$1^{\text {a }}$ Sessão - tanto as amostras de antes como depois tinham distribuição normal e então foi feito o teste " $t$ " de Student.

Tabela 47 - Para cada paciente foi feita uma avaliação antes e depois de cada uma das dez sessões de fisioterapia a que foram submetidos. Os índices variaram de 0 a 10 , com os seguintes resultados comparativos em relação a $1^{\mathrm{a}}$ sessão

Paired Samples Statistics

\begin{tabular}{llrrrr}
\hline Pair 1 & Mean & N & Std. Deviation & Std. Error Mean \\
& $\begin{array}{l}\text { 1sessão } \\
\text { antes }\end{array}$ & 5,50 & 10 & 2,799 & 0,885 \\
$\begin{array}{l}\text { 1 sessão } \\
\text { depois }\end{array}$ & 3,40 & 10 & 3,978 & 1,258 \\
\hline
\end{tabular}

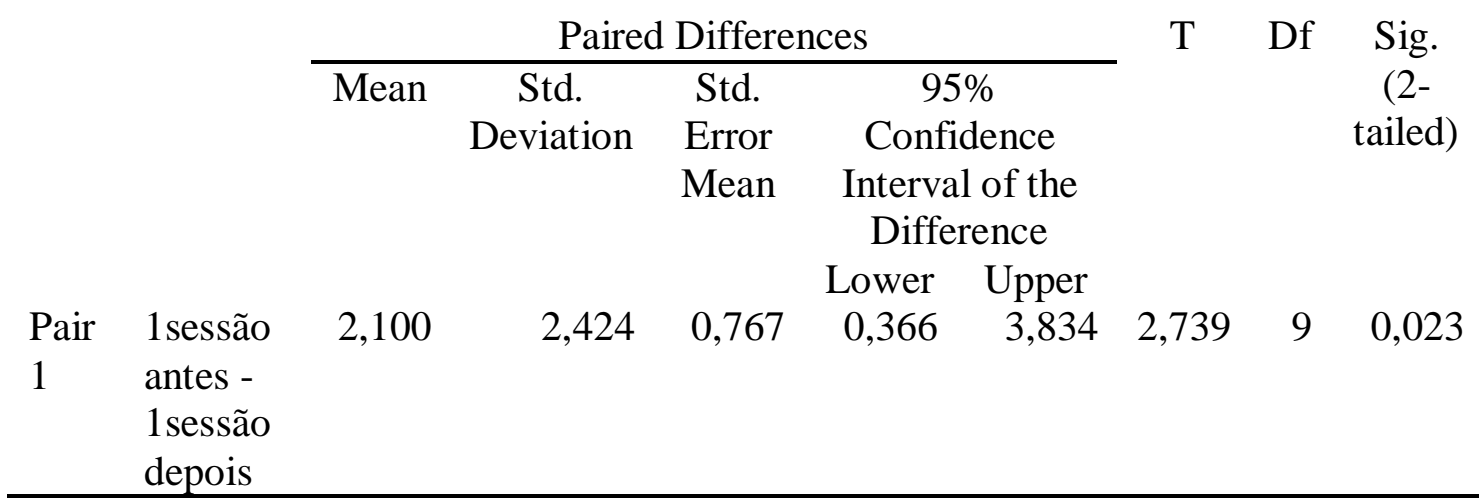

Legenda: Neste caso verificamos que houve uma diminuição dos valores após a primeira sessão, estatisticamente significativa com um $\mathrm{p}=0,023$ 
Da $2^{\mathrm{a}}$ até a $10^{\mathrm{a}}$ Sessão - tanto as amostras de antes como depois tinham distribuição não normal e então foi feito o teste de Wilcoxon, conforme tabela abaixo.

Tabela 48 - Para cada paciente foi feita uma avaliação antes e depois de cada uma das dez sessões de fisioterapia a que foram submetidos. Os índices variaram de 0 a 10 , com os seguintes resultados comparativos em relação a $2^{\mathrm{a}}$ a $10^{\mathrm{a}}$ sessão

\begin{tabular}{|c|c|c|c|c|c|c|c|c|c|}
\hline & $\begin{array}{c}2^{\mathrm{a}} \\
\text { sessão }\end{array}$ & $\begin{array}{c}3^{\mathrm{a}} \\
\text { sessão }\end{array}$ & $\begin{array}{c}4^{\mathrm{a}} \\
\text { sessão } \\
\end{array}$ & $\begin{array}{c}5^{\mathrm{a}} \\
\text { sessão } \\
\end{array}$ & $\begin{array}{c}6^{\mathbf{a}} \\
\text { sessão } \\
\end{array}$ & $\begin{array}{c}7^{a} \\
\text { sessão } \\
\end{array}$ & $\begin{array}{c}8^{a} \\
\text { sessão } \\
\end{array}$ & $\begin{array}{c}9^{a} \\
\text { sessão } \\
\end{array}$ & $\begin{array}{c}10^{\mathrm{a}} \\
\text { sessão }\end{array}$ \\
\hline $\mathrm{Z}$ & - & - & - & - & - & - & - & 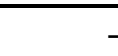 & - \\
\hline & 2,388 & 2,670 & 2,527 & 2,530 & 2,371 & 2,410 & 2,539 & 2,414 & 2,379 \\
\hline $\begin{array}{l}\text { Asymp. } \\
\text { Sig. (2- } \\
\text { tailed) } \\
\text { a. Based } \\
\text { b. Wilco }\end{array}$ & $\begin{array}{l}\text { n posit } \\
\text { on Sig }\end{array}$ & $\begin{array}{l}\text { ve rank } \\
\text { ed Rank }\end{array}$ & 0,012 & 0,011 & 0,018 & 0,016 & 0,011 & 0,016 & 0,017 \\
\hline
\end{tabular}

Legenda: Em todas as sessões tivemos valores menores na sessão depois. Os valores de $p$ mostram que as diferenças foram estatisticamente significativas conforme vemos na última linha da tabela acima (Asymp. Sig. (2-tailed). 
Discussão

5 DISCUSSÃO 
O estudo da TENS em pacientes com OA de joelhos, com objetivo terapêutico de provocar a diminuição da dor e assim melhorar a atividade funcional dos pacientes, principalmente nas atividades de vida diária. A utilização de escalas de dor, questionário de avaliação funcional possibilitou quantificar o tratamento junto aos pacientes, o que facilitou melhor o entendimento da doença, e que é possível tratar e diminuir os sintomas que limitam muito os indivíduos. Nossos resultados sugerem que a TENS pode ser utilizada como uma terapia coadjuvante ao tratamento de paciente com OA em joelho, proporcionar redução da ingestão de medicamentos quando for indicada, diminuição de custos com a medicação com a devida orientação.

OA de joelho é o mais comum tipo de osteoartrose (Andrianakos et al., 2003), e sua prevalência aumenta em paralelo com o aumento da idade populacional (Felson et al., 2000). É uma condição que está associada com dor e inflamação da capsula articular (Naredo et al., 2005), com prejuízo da estabilização muscular (Brandt et al., 2000; Cowan et al., 2001), redução da amplitude de movimento (Steultjens et al., 2000) e incapacidade funcional.

A TENS aplicada na periferia, ou seja, no local da lesão, ativa as fibras aferentes primárias, esta informação é transmitida para a medula espinhal e o resultado é a inibição tanto a nível local como também nas vias descendentes inibitórias, medula ventromedial rostral (RVM) e envolve 5-HT opióides e pode ser ativado pela substância cinzenta periaquedutal. Estudos anteriores mostram que os receptores opióides na medula espinal e RVM e receptores serotoninérgicos, muscarínicos na medula espinhal mediam a redução da hiperalgesia pelaTENS (Schmidt et al., 2007). 
Os pontos de acupuntura foram escolhidos porque são altamente reprodutíveis e convenientes (Smith et al., 1983). Em relação ao aumento de volume no joelho, houve diferenças estatisticamente significativas, o que podemos dizer que a TENS contribui para a melhora da função física, outro ponto que visa corroborar com a possível melhora é que em relação à marcha também houve evolução evidenciado pela estatística, neste mesmo ponto de discussão em que é questionado se a utilização da TENS contribuía para melhora da questão física, colocamos também que no movimento de descer também ocorreu melhorar evidenciada pela estatística nos pacientes analisados, ainda a respeito da função física, o ato de levantar-se de uma cadeira apresentou também uma evolução no curso do tratamento. No questionamento a respeito da função global do joelho durante as atividades diárias usuais, houve diferença estatisticamente significante, importante também citar que os pacientes durante o tratamento não estavam passando por outro tratamento físico, e que também não foi solicitado ao paciente que fosse interrompido a medicação, a ideia era mesmo comparar com outro método terapêutico.

No item que questionava ao paciente a lesão em seu joelho, e perguntava como classificaria o seu nível atual de atividade diária, os resultados foram que houve diferenças estatisticamente significativas nos pacientes analisados. No questionamento desde o inicio do tratamento do joelho como descreveria o progresso, os resultados informam que houve diferenças estatisticamente significativas.

Em um estudo que perguntava se a TENS melhorava o desempenho físico em pacientes com osteoartrose, a análise da amplitude de movimento mostrou uma melhora 
significante e que também em relação ao grupo placebo foi melhor a amplitude de movimento em duas semanas de tratamento (Law et al., 2004a ).

Na revisão sistemática produzida por (Oziris et al., 2000), foram incluídos 294 pacientes com diagnósticos de OA de joelho definido pelos critérios do Colégio Americano de Reumatologia. Os itens avaliados foram a relação intensidade/e alivio da dor medida pela VAS, pelo inchaço, força muscular do quadríceps, distância percorrida e o tempo, amplitude de movimento do joelho, circunferência do joelho. Os resultados demonstraram um efeito positivo, quando comparado com placebo, em todas as aplicações; a TENS modo burst ou TENS acupuntura foi duas vezes melhor que a TENS convencional quando comparado com placebo, embora isso fosse notado em apenas dois ensaios dos sete avaliados, e o efeito positivo da TENS relaciona-se com um número repetido de sessões.

A revisão sistemática produzida por (Bjordal et al., 2007), 11 ensaios selecionados, 9 ensaios incluídos na revisão, com um total de 333 pacientes, com diagnóstico de OA pelos critérios do Colégio Americano de Reumatologia e ou por radiografia com sintomatologia de mais de 3 meses. Dos 333 pacientes, 277 recebeu uma frequência de 1 a $150 \mathrm{~Hz}$, por pelo menos 20 minutos de duração a sessão com um mínimo 5 sessões de tratamento; os resultados foram redução na intensidade da dor pela WOMAC ou VAS.

Uma única sessão de tratamento com a TENS ou tratamento com a TENS e exercício, produziu significativamente melhor redução da dor que somente o exercício. Em mais de quatro semanas de tratamento vários graus de redução da dor foram achados em diferentes grupos, mas nos quatro protocolos de tratamento não mostrou diferença significante entre os grupos estudados, até o final do protocolo (Cheing et al., 2002) 
Tanto TENS de alta frequência e baixa frequência resultou em uma inversão da hiperalgesia imediatamente após o tratamento. A TENS parece ser mais eficaz na redução da dor referida ou hiperalgesia secundária (sluka et al., 1998).

As escalas de avaliação unidimensional têm por concepção somente avaliar um elemento da experiência da dor, o qual é a intensidade. Em medidas multidimensionais que é uma das formas de avaliação do estudo em questão, possibilita uma melhor compreensão da dor para o indivíduo. No caso dos pacientes idosos, eles apresentam dificuldade em assumir a sua dor com sendo mais intensa, o que pode levar a esses indivíduos a escolherem níveis menores de dor em medidas de intensidade, subestimando este sintoma. A utilização de uma escala multidimensional em pacientes idosos possibilita uma avaliação mais adequada da dor uma vez que existem outras alterações de ordem qualitativa no que se refere à dor e à idade e não somente à intensidade (Gagliese e Melzack, 1997).

Ao aplicar o questionário de dor Mcgill, em pacientes idosos com dor crônica em decorrência de doenças ortopédicas, a confiabilidade intra-examinador foi considerada "quase perfeita". O índice de classificação de dor sensorial, isoladamente apresentou uma confiabilidade pequena, já em relação ao padrão temporal de dor, verificou-se que a confiabilidade intra-examinador para interexaminador indicou uma confiabilidade como "quase perfeita" (Santos et al., 2006).

O questionário de dor McGill com todos os seus caracteres tem uma finalidade em cada grupo de palavras quando é aplicado. O grupo sensorial-discriminativo (subgrupos de 1 a 10) refere-se às propriedades mecânicas, térmicas, experiências vividas e espaciais da dor; o grupo afetivo-motivacional (subgrupos de 11 a 15) descreve a dimensão afetiva nos 
aspectos de tensão, medo e respostas neurovegetativas; os descritores do componente cognitivo-avaliativo (subgrupo 16) permitem, ao doente, expressar a avaliação global da experiência dolorosa. Os subgrupos de 17 a 20 compreendem itens de miscelânea. Cada subgrupo é composto por 2 a 6 descritores qualitativamente.

O questionário de dor McGill com os seus caracteres relacionados ao grupo sensorial-discriminativo (subgrupos de 1 a 10) refere-se às propriedades mecânicas, térmicas, experiências vividas e espaciais da dor (Pimenta e Teixeira, 1996). Os resultados sugerem uma melhora com a utilização da TENS para o tratamento da dor em joelhos com OA, descrita através do questionário McGill, neste grupo de descritores observou-se que a escolha de determinados descritores na $1^{\mathrm{a}}$ entrevista foi diminuída em relação à $2^{\mathrm{a}}$ entrevista e também na $3^{\mathrm{a}}$ entrevista, o que sugere uma melhora.

O sistema de avaliação intitulado Cincinnati Knee Rating system (Lequesne et al., 1987 e Noyes et al., 1991) e o Lysholm knee scale (Tgner e Lysholm, 1985), foram desenvolvidos para avaliar a função ligamentar do joelho, enquanto que o Western Ontario and McMaster Universities Osteoarthritis Index (Bellamy et al., 1988) e o Lequesne Algofunctional Index (Lequesne et al., 1987) foram desenvolvidos para avaliar a função do joelho com OA.

Na presença de condições clínicas concomitantes, como por exemplo, uma lesão ligamentar combinada com dor patelo-femoral ou OA, torna-se difícil selecionar o instrumento de avaliação funcional mais adequado (Gonçalves e Rosado, 2005).

No final da década de 90, foi desenvolvido, no departamento de Fisioterapia da Universidade de Pittsburgh (Pensilvania, Estados Unidos da América), o Knee Outcome Survey, uma medida de avaliação funcional do joelho passível de ser aplicada em 
diferentes condições clínicas específicas (exclusivas ou coexistentes), incluindo lesões ligamentates e meniscais, dor patelo-femoral e OA (Borsa et al, 1998 \& Irrgang et al., 1998).

A TENS nível sensorial está implicada com a liberação de opiódes endógenos, mais especificamente meta-encefalina e dinorfina analisado no fluído cerebroespinhal de humanos (Han et al., 1991). A proposta da TENS nível sensorial é ativar seletivamente os aferentes cutâneos não nociceptivos $(\mathrm{A} \beta)$, para iniciar o mecanismo segmental antinociceptivo, indicando a ativação seletiva das fibras nervosas de grande diâmetro para o sistema nervoso central, sem simultaneamente ativar fibras $\mathrm{A} \delta$ e $\mathrm{C}$ de pequeno diâmetro (Johnson, 2001). Em uma metanálise de 294 pacientes com OA em joelhos descreveu melhor alívio da dor e redução na rigidez do joelho comparado com o tratamento placebo (Osiri et al., 2000).

Em uma análise dos efeitos analgésicos em diferentes frequências da TENS, que tinha por objetivo controle da dor induzida pelo frio em indivíduos normais, os resultados deste estudo demonstrou que a maior analgesia ocorreu em frequências entre 20 e $80 \mathrm{~Hz}$ sendo que abaixo e acima desta variação foram menos efetivas (Johnson et al., 1989).

O papel da frequência na aplicação da TENS, a intensidade e local são fundamentais para alcançar ótimos efeitos hipoalgésicos, durante e após a estimulação (Chesterton et al., 2003).

A influência da TENS sobre a amplitude de movimento, ou seja, atividades funcionais como subir e descer escadas, deambular mostrou melhora significativa nas três frequências pesquisadas, o que não aconteceu no grupo placebo. Dor é um dos principais 
fatores que impedem o movimento, em todos os grupos a dor foi reduzida significativamente (Law e Cheing, 2004).

Em uma metaanálise que avaliou dor nos joelhos com origem na osteoartrose e também dor crônica de origem músculoesquelética os resultados tem sido mais positivo, sugerindo que a TENS é superior a TENS placebo em relação à dor e rigidez (Bjordal et al., 2007 e Johnson e Martinson, 2007).

Clinicamente, TENS é aplicada em diferentes frequências, intensidades e tempo duração de estimulação, a frequência de estimulação é amplamente classificado como de alta frequência $(>50 \mathrm{~Hz})$, baixa frequência baixa $(<10 \mathrm{~Hz})$, a intensidade é determinada pela resposta do paciente em ambos nível sensorial ou nível motor (Sluka e Walsh, 2003).

A escala de atividade da vida diária Knee Outcome Survey apresenta dois fatores dominantes: um que reflete a combinação de sintomas e limitação funcional e outro somente sintoma. No estudo utilizei a TENS como método de tratamento em que o objetivo era diminuição da dor e também a aplicação da escala que avaliava as atividades de vida diária e a observação em qual amplitude a TENS colaboraria para melhora funcional. Em relação à avaliação da dor, mesmo com a amostra reduzida ocorreu diminuição da dor no andamento dos três questionários como também em relação ao início do tratamento e o progresso que era questionado junto ao paciente, no âmbito de sintomas e limitação funcional a questão que envolvia o aumento de volume no joelho produziu diferença estatisticamente significativa, ainda neste item a capacidade de marcha apresentou evolução no andamento do tratamento juntamente com a capacidade de descer escadas e levantar-se de uma cadeira. A escala também mostrou que na avaliação da função global do joelho o qual questionava a condição funcional do joelho, ocorreu uma 
evolução que demonstrou uma diminuição anotada nas avaliações do questionário pela marcação do item que compreendia uma situação normal, quase normal, anormal e muito anormal, evidenciado pela avaliação estatística. Em uma relação temporal em que a questão funcional no início do tratamento foi avaliada e observada no decorrer do tratamento pelo questionário demonstrou que a TENS mesmo como único fator de diminuição da dor possibilitou alívio de sintomas e melhora funcional.

Em uma abordagem funcional e sintomática a TENS sugere uma melhora no quadro doloroso associado à função cinesiológica do joelho nos pacientes com OA demonstrado pelos dados estatísticos da pesquisa.

A proposta principal foi fazer uma abordagem da TENS em pacientes com osteoartrose de joelho, com objetivo de aliviar a dor, utilizando conjuntamente escalas de dor e complementando com a avaliação funcional. Isso sugere uma melhor compreensão do processo patológico da doença pelo paciente e estimula o paciente no processo de tratamento, uma vez que a adesão apresenta dificuldades. 


\section{Conclusão}

6 CONCLUSÃO 
CONCLUSÃO

Os resultados sugerem que a TENS nível sensório aplicado em pacientes com OA de joelho contribui para diminuição da dor e melhora funcional. Os benefícios parecem mais claros à medida que quantificamos a dor e aplicamos essa relação nas atividades da vida diária através das inúmeras escala de avaliação funcional, a dor sendo questionada a todo o momento possibilita mudar estratégias de tratamento juntamente com todas as atividades cotidianas, assim poderia ser possível conseguir melhor adesão. 
7 Anexos 


\section{Questionário da Dor}

McGill - Melzack

Nome do paciente

Prontuário №

Idade

Diagnóstico (s):

Categoria clínica:

Analgésicos (se já administrado)

1. Tipo

2. Dosagem

3. Período administrado em relação a este teste

Inteligência do paciente: marque com um círculo o número que melhor representa à estimativa
1(baixa)
2
3
4
$5($ alta $)$

Este questionário foi elaborado para nos informar sobre a sua dor. As quatro principais questões são:

1. Qual a localização de sua dor?

2. Qual o tipo?

3. Como ela se altera no decorrer do tempo?

4. Qual a sua intensidade?

É importante que você nos informe como é a sua dor agora. Por favor, siga as instruções apresentadas no início de cada parte.

R. Melzack, Oct. 1970 
Parte 1 Qual a localização da sua dor?

Por favor, marque no desenho abaixo as áreas onde você sente dor. Nas áreas marcadas, indique com um E quando ela for externa e com um I quando ela for interna. Indique com EI quando for externa e interna.

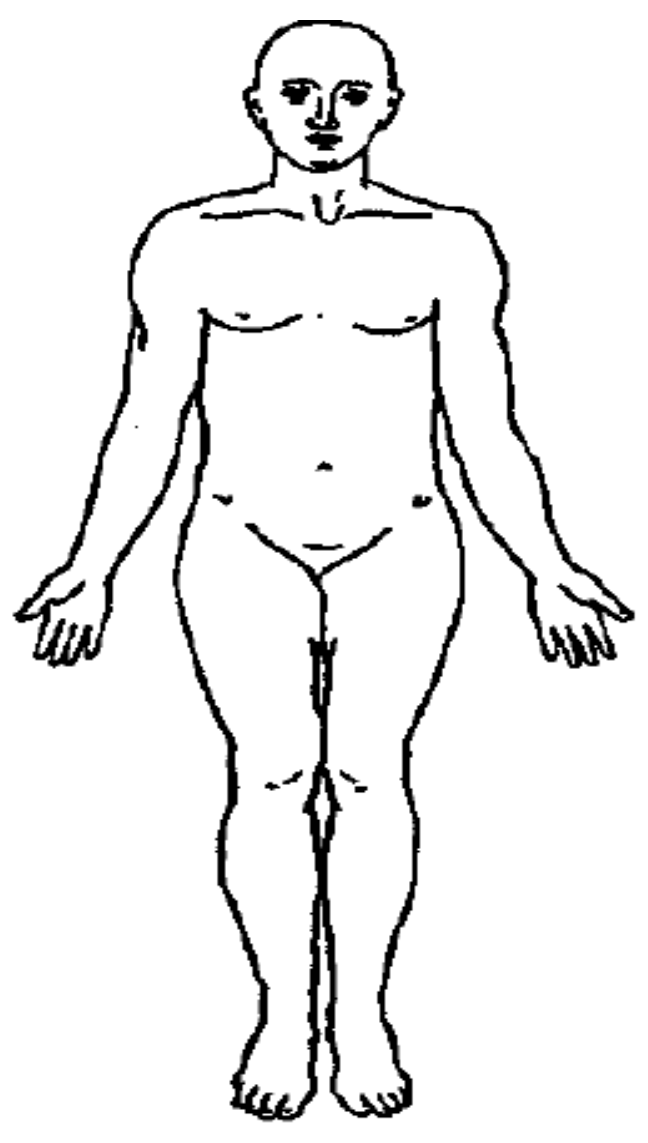

FRENTE

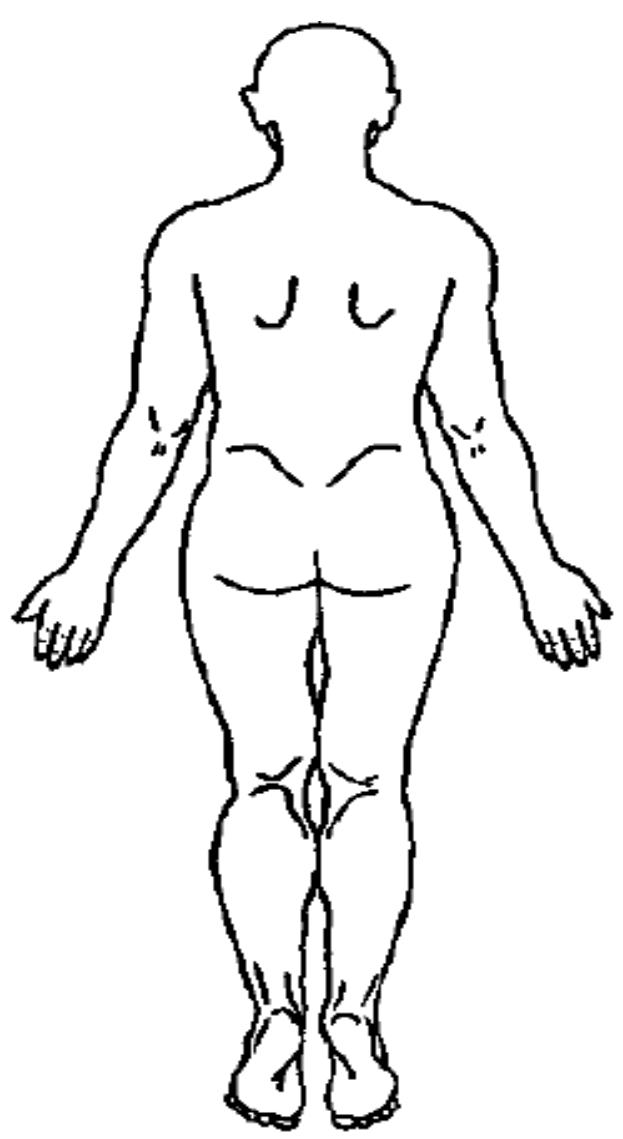

COSTAS

Parte 2 Qual o tipo?

Alguns dos termos abaixo descrevem sua dor atual. Marque com um círculo apenas aqueles que melhor a descrevem. Deixe de lado qualquer categoria não adequada. Utilize apenas um termo de cada categoria, o que melhor se aplica à sua dor.

(Não escolha aquelas que não se aplicam a seu caso. Escolha somente uma palavra de cada grupo). 
(dimensão sensitiva, 1-10; dimensão afetiva, 11-15; dimensão avaliativa, 16; miscelânea, 17-20).

\begin{tabular}{|c|c|c|c|}
\hline 1 & 2 & 3 & 4 \\
\hline ( )Vibração & ( )Pontada & ( )Agulhada & ( )Fina \\
\hline ( )Tremor & ( )Choque & ( )Perfurante & ( ) Cortante \\
\hline ( )Pulsante & ( ) Tiro & ( )Facada & ( )Estraçalha \\
\hline ( ) Latejante & & ( )Punhalada & \\
\hline ( )Como batida & & ( )Em lança & \\
\hline \multicolumn{4}{|l|}{ ( )Como pancada } \\
\hline 5 & 6 & 7 & 8 \\
\hline ( )Beliscão & ( )Fisgada & ( )Calor & ( )Formigamento \\
\hline ( )Aperto & ( )Puxão & ( )Queimação & ( )Coceira \\
\hline ( )Mordida & ( )Em torção & ( )Fervente & ( )Ardor \\
\hline ( )Cólica & & ( )Em brasa & ( )Ferroada \\
\hline \multicolumn{4}{|l|}{ ( )Esmagamento } \\
\hline 9 & 10 & 11 & 12 \\
\hline ( )Mal localizada & ( )Sensível & ( )Cansativa & ( )Enjoada \\
\hline ( )Dolorida & ( )Esticada & ( )Exaustiva & ( )Sufocante \\
\hline ( )Machucada & ()Esfolante & & \\
\hline ( )Doída & ( )Rachando & & \\
\hline \multicolumn{4}{|l|}{ ( )Pesada } \\
\hline 13 & 14 & 15 & 16 \\
\hline ( )Castigante & ( )Amedrontadora & ( )Miserável & ( )Chata \\
\hline ( )Atormenta & ( )Apavorante & ( )Que cega & ( )Que incomoda \\
\hline \multirow[t]{3}{*}{ ( )Cruel } & ( )Aterrorizante & & ( )Desgastante \\
\hline & ( )Maldita & & ( )Forte \\
\hline & ( )Mortal & & ( )Insuportável \\
\hline 17 & 18 & 19 & 20 \\
\hline ( )Espalha & ( )Aperta & ( )Fria & ( )Aborrecida \\
\hline ( )Irradia & ( )Adormece & ( )Gelada & ( )Dá nausea \\
\hline ( )Penetra & ( )Repuxa & ( )Congelante & ( )Agonizante \\
\hline ( )Atravessa & ( )Espreme & & ( )Pavorosa \\
\hline & ( )Rasga & & ( )Torturante \\
\hline
\end{tabular}


Parte 3 Como a sua dor muda com o tempo?

1. Qual (is) palavra (s) você usaria para descrever o padrão de sua dor?

1
2

3
Contínua ( )
Crescente ( )
Constante( )
( )Rítmica
( )Breve
( )Periódico-Momentânea
( ) Momentânea
( )Intermitente
( )Transitória

2. Que tipo de coisas alivia sua dor?

3. Que tipo de coisas aumenta sua dor?

\section{Parte 4 Quão forte é a sua dor?}

As pessoas concordam que as 5 palavras a seguir representam a dor de intensidade crescente. São elas:

\begin{tabular}{|c|c|c|c|c|}
\hline 1 & 2 & 3 & 4 & 5 \\
\hline Leve & Incômoda & Angustiante & Horrível & Excruciante \\
\hline
\end{tabular}

Para responder as questões abaixo, escreva o número da palavra mais adequada no espaço ao lado da questão.

1.Qual palavra descreve a sua dor exatamente neste momento?

2. Qual palavra a descreve no pior momento?

3. Qual palavra descreve a pior dor de dente que você já sentiu? 
4. Qual palavra descreve a pior dor de cabeça que você já sentiu?

5. Qual palavra descreve a pior dor de estômago que você já sentiu?

Escala de Avaliação Análoga da Dor de Mcgill - Melzack

$\mathrm{Na}$ Escala da Dor de Mcgill os pacientes que selecionam as palavras que melhor descrevem a sua dor.

De acordo com as escolhas obtém-se uma pontuação na qual a dor do paciente será classificada como: sensorial, afetiva, avaliativa e mista.

Questionário de Dor de McGill

Como a sua dor se parece?

Algumas das palavras abaixo descrevem sua dor atual. Faça um círculo SOMENTE nas palavras que a descrevem melhor. Deixe fora qualquer categoria que não seja adequada. Use apenas em cada categoria apropriada a que melhor se aplica.

Sensorial: 1-8 Avaliativa: 16

Afetiva : 9-15 Mista: 17-20

Descritor escolhido possibilita quantificar a dor

Número de descritores escolhidos Índice de dor

\begin{tabular}{|l|l|l|l|}
\hline Sensitivos & & Sensitivo & \\
\hline Afetivos & & Afetivo & \\
\hline Avaliativas & & Avaliativo & \\
\hline Miscelânea & & Miscelânea & \\
\hline Total & & Total & \\
\hline
\end{tabular}

Escala Analógica visual da dor

Permite ao paciente quantificar visualmente a magnitude de sua dor sobre uma linha contínua de $10 \mathrm{~cm}$.

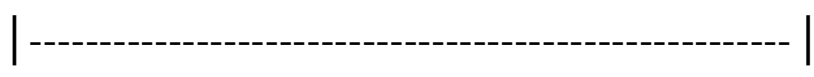

Sem dor Dor máxima 
Por favor, marque na linha abaixo onde o seu "nível de dor" foi mais intenso em qualquer ocasião.

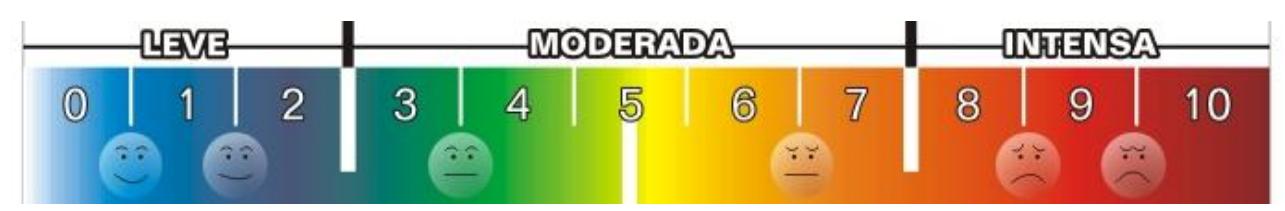

Instruções:

O questionário a seguir foi elaborado para determinar os sintomas e as limitações que você sente por causa do joelho ao executar suas atividades diárias habituais. Por favor, responda cada questão assinalando à afirmativa que melhor descreve você durante os últimos 1 a 2 dias. Para uma questão, mais de uma das afirmativas podem descrevê-lo, mas, por favor, assinale SOMENTE aquela que melhor o descreve durante as suas atividades cotidianas.

\section{Sintomas}

1. Em que grau a dor em seu joelho afeta o seu nível de atividade diária?

__ Nunca tenho dor no joelho.

__ Tenho dor no joelho, mas ela não afeta minha atividade diária.

A dor afeta a minha atividade discretamente.

A dor afeta a minha atividade moderadamente

A dor afeta a minha atividade acentuadamente.

A dor no joelho impede-me de realizar todas as atividades diárias. 
2. A que grau o rangido ou crepitação do seu joelho afeta o seu nível de atividade diária?

__ Meu joelho nunca range nem apresenta atrito.

__ Meu joelho range e apresenta atrito, mas não afeta minha atividade diária.

__ O rangido ou o atrito afeta minha atividade discretamente.

_ O rangido ou o atrito afeta minha atividade moderadamente.

_ $\mathrm{O}$ rangido ou o atrito afeta minha atividade acentuadamente.

__ O rangido ou o atrito no joelho impede-me de executar todas as atividades diárias.

3. Em que grau a rigidez no seu joelho afeta o seu nível de atividade diária? Nunca apresento rigidez no joelho. Apresento rigidez no joelho, mas ela não afeta minha atividade diária. A rigidez afeta minha atividade discretamente. A rigidez afeta minha atividade moderadamente. A rigidez afeta minha atividade acentuadamente. A rigidez no joelho impede-me de executar todas as atividades diárias.

4. A que grau o aumento de volume no joelho afeta o seu nível de atividade diária? __ Nunca apresento aumento de volume no joelho.

__ Eu apresento aumento de volume no joelho, mas ele não afeta minha atividade diária.

__ O aumento de volume afeta minha atividade discretamente.

__ O aumento de volume afeta minha atividade moderadamente. 
_ O aumento de volume afeta minha atividade acentuadamente.

_ $\mathrm{O}$ aumento de volume no joelho impede-me de executar todas as atividades diárias.

5. Em que grau o deslizamento do joelho afeta o seu nível de atividade diária?

_ Nunca apresento deslizamento do joelho.

__ Eu apresento deslizamento do joelho, mas ele não afeta a minha atividade diária.

_ O deslizamento do joelho afeta minha atividade discretamente.

_ $\mathrm{O}$ deslizamento do joelho afeta minha atividade moderadamente.

__ O deslizamento do joelho afeta minha atividade acentuadamente.

__ O deslizamento do joelho impede-me de executar todas as atividades diárias.

6. Em que grau o bloqueio do seu joelho afeta o seu nível de atividade diária?

__ Nunca apresento bloqueio do joelho.

__ Eu apresento bloqueio do joelho, mas ele não afeta o nível de minhas atividades diárias.

__ O bloqueio do joelho afeta minha atividade discretamente

_ O bloqueio do joelho afeta minha atividade moderadamente.

_ _ O bloqueio do joelho afeta minha atividade intensamente.

__ O bloqueio do joelho impede-me de executar todas as atividades diárias.

7. Em que grau a fraqueza ou falta de força de seu membro inferior afeta o seu nível de atividade diária?

__ Nunca sinto fraqueza no membro inferior. 
Eu sinto fraqueza no membro inferior, mas ela não afeta minha atividade diária.

A fraqueza do membro inferior afeta minha atividade ligeiramente.

A fraqueza do membro inferior afeta minha atividade moderadamente.

A fraqueza do membro inferior afeta minha atividade intensamente.

A fraqueza do membro inferior impede-me de realizar todas as atividades diárias.

Incapacidade Funcional nas Atividades da Vida Diária

8. Como o seu joelho afeta sua capacidade de marcha?

__ Meu joelho não afeta minha capacidade de marchar.

__ Eu sinto dor no joelho quando ando, mas ela não limita minha capacidade de andar.

_ Meu joelho impede-me de andar mais de 1.600 metros.

_ Meu joelho impede-me de andar mais de 800 metros.

_ _ Meu joelho impede-me de andar mais de um quarteirão

_ Meu joelho impede-me de andar.

9.Por causa do seu joelho, você anda com muletas ou uma bengala?

_ _ Sou capaz de andar sem muletas ou bengala.

__ Meu joelho obriga-me a andar com uma muleta ou uma bengala.

__ Meu joelho obriga-me a andar com duas muletas.

Por causa do meu joelho, não consigo andar mesmo com muletas.

10. O seu joelho faz você mancar quando anda?

__ Sou capaz de andar sem mancar. 
Às vezes meu joelho faz com que eu manque.

_ Por causa do meu joelho, não sou capaz de andar sem mancar.

11. Como o seu joelho afeta sua capacidade de subir escadas?

__ Meu joelho não afeta minha capacidade de subir escadas.

_ Tenho dor no joelho quando subo escadas, mas ela não limita minha capacidade de fazê-lo.

__ Sou capaz de subir escadas normalmente, mas preciso usar um corrimão.

Sou capaz de subir escadas um degrau de cada vez com o auxílio de corrimão.

_ _ Tenho que usar muletas ou uma bengala para subir escadas.

Não sou capaz de subir escadas.

12. Como o seu joelho afeta sua capacidade de descer escadas?

__ Meu joelho não afeta minha capacidade de descer escadas.

__ Tenho dor nos joelhos quando desço escadas, mas ela não limita minha capacidade de fazê-lo.

_ Sou capaz de descer escadas normalmente, mas necessito usar um corrimão.

__ Sou capaz de descer escadas um degrau de cada vez com auxílio de um corrimão.

__ Tenho de usar muletas ou uma bengala para descer escadas.

__ Não sou capaz de descer escadas.

13. Como o seu joelho afeta a capacidade de ficar em pé?

__ Meu joelho não afeta minha capacidade de ficar em pé. 
Sou capaz de ficar em pé durante um período ilimitado.

__ Sinto dor no joelho quando fico em pé, mas ela não limita minha capacidade de fazê-lo.

_ Por causa do joelho, não sou capaz de ficar em pé mais de 1 hora.

__ Por causa do joelho, não sou capaz de ficar em pé mais de $1 / 2$ hora.

Por causa do joelho, não sou capaz de ficar em pé mais de 10 minutos.

Não sou capaz de ficar em pé por causa do joelho.

14. Como o seu joelho afeta sua capacidade de se ajoelhar?

__ Meu joelho não afeta minha capacidade de ajoelhar.

Posso permanecer ajoelhado durante um período ilimitado.

__ Sinto dor ao ajoelhar, mas ela não limita minha capacidade de ajoelhar.

__ Não consigo permanecer ajoelhado por mais de 1 hora.

__ Não consigo permanecer ajoelhado por mais de $1 / 2$ hora.

__ Não consigo permanecer ajoelhado por mais de 10 minutos.

_ Não consigo permanecer ajoelhado.

15. Como o seu joelho afeta a capacidade de agachar-se?

__ Meu joelho não afeta minha capacidade de agachamento.

__ Posso agachar completamente.

__ Não sou capaz de agachar mais de $3 / 4$ da altura.

_ Não sou capaz de agachar mais da metade da altura.

__ Não sou capaz de agachar mais de $1 / 4$ para baixo.

_ Sou totalmente incapaz de agachar. 
16. Como o seu joelho afeta a capacidade sentar-se com o joelho dobrado? __ Meu joelho não afeta minha capacidade de me sentar com o joelho flexionado. Sou capaz de permanecer sentado durante um período ilimitado.

__ Sinto dor ao permanecer sentado com o joelho flexionado, mas ela não limita minha capacidade de fazê-lo.

_ Não consigo permanecer sentado com o joelho flexionado por mais de 1 hora.

__ Não consigo permanecer sentado com o joelho flexionado por mais de $1 \frac{1}{2}$ hora.

__ Não consigo permanecer sentado com o joelho flexionado por mais de 10 minutos.

__ Não consigo permanecer sentado com o joelho flexionado.

17. Como o seu joelho afeta sua capacidade de levantar-se de uma cadeira?

__ Meu joelho não afeta a capacidade de levantar-me de uma cadeira.

__ Sinto dor ao elevar-me da posição sentada, mas ela não afeta minha capacidade de fazê-lo.

_ Por causa do joelho, somente posso levantar-me de uma cadeira com o auxílio das mãos e braços.

__ Por causa do joelho, sou incapaz de levantar-me de uma cadeira.

18. Como você classificaria o seu nível atual da função do joelho durante as suas atividades diárias usuais em uma escala de 0 a 100, com 100 sendo o seu nível de função do joelho antes da sua lesão? 
19. Como você classificaria a função global do seu joelho durante as suas atividades diárias usuais?

normal

quase normal

anormal

muito anormal

20. Como resultado da lesão em seu joelho, como você classificaria o seu nível atual de atividade diária?

normal

quase normal

anormal

muito anormal

21. Desde o início do tratamento do joelho, como você descreveria o seu progresso? muito melhor

__ um pouco melhor

__ nem melhor nem pior

_ _ um pouco pior muito pior

Alterações no Nível de Atividade Diária

Por favor, utilize a escala seguinte para responder às questões $\mathrm{A}-\mathrm{C}$ abaixo. 
1 = Eu era capaz de executar trabalho físico ilimitado, o qual incluía levantar peso e subir escada.

2 = Eu era capaz de executar trabalho físico limitado, o qual incluía levantar peso e subir escada.

3 = Eu era capaz de executar atividades leves ilimitadas, as quais incluíam andar sobre superfícies planas e subir escada.

4 = Eu era capaz de executar atividades leves limitadas, as quais incluíam andar sobre superfícies planas e subir escada.

$5=$ Eu era incapaz de executar atividades leves, as quais incluíam andar sobre superfícies planas e subir escadas.

A.___ Antes da lesão de seu joelho, como você descreveria o seu nível usual de atividade? Favor indicar somente o nível de atividade MAIS ALTO que descreveria você antes da lesão de seu joelho.

B.___ Antes da cirurgia ou do tratamento de seu joelho, como você descreveria a sua atividade diária usual? Favor indicar somente o nível de atividade MAIS ALTO que descreveria você antes da cirurgia ou do tratamento do seu joelho.

C. ___ Como você descreveria o seu nível atual de atividade diária? Favor indicar somente o nível de atividade MAIS ALTO que descreve você nos últimos 1 ou 2 dias. 
8 REFERÊNCIAS 


\section{REFERÊNCIAS}

Altman, RD, Asch, E, Bloch, D. et al. Development of criteria for the classification and reporting of osteoarthritis. Classification of osteoarthritis of the knee. Arthritis Rheum. 1986;29:1039-49.

Andrianakos A, Trontzas P, Christoyannis F, Dantis P, Voudouris C, Georgountzos A, et al. Prevalence of rheumatic diseases in Greece: a cross-sectional population based epidemiological study. The ESORDIG Study. J Rheumatol. 2003;30(7):1589-601.

Bassbaum AL, Fields HL: Endogenous Pain control mechanism: review and hypothesis. Ann Neurol.1978;4:451-462.

Bellamy N, Buchanan WW, Goldsmith CH, Campbell J, Stitt LW. Validation study of WOMAC: a health status instrument for measuring clinically important patient relevant outcomes to antirheumatic drug therapy in patients with osteoarthritis of the hip or knee. $J$ Rheumatol.1988;15(12):1833-40.

Bjordal JM, Johnson MI, Lopes-Martins RA, Bogen B, Chow R, Ljunggren AE. Shortterm efficacy of physical interventions in osteoarthritis knee pain. A systematic review and meta-analysis of randomized placebo-controlled trials. BMC Musculoskelet Disord.2007; $8: 51$. 
Borsa PA, Lephart SM, Irrgang JJ. Sport-Specificity of Knee Scoring Systems to Assess Disability in Anterior Cruciate Ligament-Deficient Athletes. J Sport Rehabil.1998;7:4460.

Brandão LR, Hasegawa TM, Borjaille BP. Medicina Física na Reumatologia . Tema de Reumatologia.2005;6(4):116-20

Brandt KD, Heilman DK, Slemenda C, Katz BP, Mazzuca S, Braunstein EM, et al. A comparison of lower extremity muscle strength, obesity, and depression scores in elderly subjects with knee pain with and without radiographic evidence of knee osteoarthritis. $J$ Rheumatol.2000;27(8):1937-46.

Cameron, MH. Physical agents in rehabilitation: from research to practice. Philadelphia: WB Saunders;2003.

Campbell JN, Taub A. Local analgesia from percutaneous electrical stimulation: a peripheral mechanism. Arch Neurol.1973;28(5):347-350.

Chabal C, Fishbain DA, Weaver M, Lisa W. Long term transcutaneous electrical nerve stimulation (TENS) use: impact on medication utilization and physical therapy costs. Clin J Pain.199814(1):66-73.

Chapmam CR et al. Pain measurement: an overview. Pain.1985;22:1-31. 
Cheing GL, Hui-Chan CW, Chan KM. Does four weeks of TENS and/or isometric exercise produce cumulative reduction of osteoarthritic knee pain? Clin Rehabil.2002;16(7):749760.

Cheing GL, Luk ML: Transcutaneous electrical nerve stimulation for neuropathic pain. $J$ Hand Surg Br.2005;30(1):50-55.

Chesterton LS, Foster NE, Wright CC, Baxter GD, Barlas P. Effects of TENS frequency, intensity and stimulation site parameter manipulation on pressure pain thresholds in healthy human subjects. Pain.2003;106(1-2):73-80.

Cowan SM, Bennell KL, Hodges PW, Crossley KM, McConnell J. Delayed onset of electromyographic activity of vastus medialis obliquus relative to vastus lateralis in subjects with patellofemoral pain syndrome. Arch Phys Med Rehabil.2001;82(2):183-9.

Ernest E, Fialka V: Ice freezes Pain? A review of the clinical effectiveness of analgesic cold therapy. J Pain Symp Mgmt.1994;9(1):56-59.

Felson DT, Lawrence RC, Hochberg MC, McAlindon T, Dieppe PA, Minor MA et al. Osteoarthritis: new insights. Part 2: treatment approaches. Ann Intern Med.2000; 7;133(9):726-37. 
Gagliese L, Melzack R. Chronic pain in elderly people. Pain.1997;70(1):3-14.

Giorgi RDN. A osteoartrose na prática clínica; temas de reumatologia.2005;6(1):17-30.

Gopalkrishnan P, Sluka KA. Effect of varying frequency, intensity, and pulse duration of transcutaneous electrical nerve stimulation on primary hyperalgesia in inflamed rats. Arch Phys Med Rehabil.2000;81(7):984-90.

Greenspan A. Radiologia Ortopédica. Rio de Janeiro: Guanabara Koogan;2001;432.

Han JS, Chen XH, Sun SL et al. Effect of low- and high-frequency TENS on Met enkephalin-Arg-Phe and dynorphin A immunoreactivity in human lumbar CSF. Pain. $1991 ; 47: 295-98$.

Holmgren E. Increase in pain threshold as a function of conditioning electrical stimulation. Am J Clin Med.1975;3:133.

Irrgang JJ, MR Safran, FH Fu. “The Knee: Ligamentous and meniscal injuries”. In: Athletic Injuries and Rehabilitation. Philadelphia: Sauders;1996.

Irrgang JJ, Ho H, Harner CD, Fu FH. Use of the International Knee Documentation Committee guidelines to assess outcome following anterior cruciate ligament reconstruction. Knee Surg Sports Traumatol Arthrosc.1998;6(2):107-14. 
Johnson MI et al. Analgesic effect of different frequencies of transcutaneous electrical nerve stimulation on cold induced pain in normal subjects. Pain.1989;39:231-36.

Johnson MI. Transcutaneous electrical nerve stimulation (TENS) and TENS like devices: do they provide pain relief? Curr Rev Pain.2001;8:121-158.

Johnson M, Martinson M. Efficacy of electrical nerve stimulation for chronic musculoskeletal pain: a meta-analysis of randomized controlled trials. Pain.2007;130:15765

Keyes GW. Graham, AJ Carr, RK Miller, JW Goodfellow. The radiographic classification of medial gonarthrosis. Acta Orthop Scand.1992;63(5):497-501.

Law PP, Cheing GL, Tsui AY. Does transcutaneous electrical nerve stimulation improve the physical performance of people with knee osteoarthritis? J clin rheumatol.2004; 10:295-299.

Law PP, Cheing GL. Optimal stimulation frequency of transcutaneous electrical nerve stimulation on people with knee osteoarthritis. J Rehabil Med.2004;36(5):220-5.

Lawrence JS, Bremner JM, Bier F. Osteoarthrosis Prevalence in the population and relationship between symptoms and x ray changes. Ann Rheum Dis.1966;25:1-24. 
Lawrence RC, Hockberg MC, Kelsey JL. Estimates of the prevalence of selected arthritis and musculoskeletal diseases in the United States. J Rheumatol.1989;16:427-41.

Lawrence RC, Helmick CG, Arnett FC, Deyo RA, Felson DT, Giannini EH, et al. Estimates of the prevalence of arthritis and selected musculoskeletal disorders in the United States. Arthritis Rheum.1998;41(5):778-99.

Lequesne MG, Mery C, Samson M, Gerard P. Indexes of severity for osteoarthritis of the hip and knee. Validation--value in comparison with other assessment tests. Scand $J$ Rheumatol Suppl.1987;65:85-9.

Lone AR, Wafai ZA, Buth BA, Wani TA, Koul PA, Khan SH. Analgesic efficacy of transcutaneous electrical nerve stimulation compared with diclofenac sodium in osteoarthritis of the knee. Physiotherapy.2003;89(8):478-85.

Maiani G, Sanavio E. Semantics of pain in italy: the italian version of Mcgill pain questionnaire. Pain.1985;22:399-405.

McMaster WC, Liddie S: Cryotherapy influence on posttraumatic limb edema. Clin Orthop Relat Res.1980;150:283-287.

Melzack R, Wall PD. Pain mechanism a new theory. Science.1965;150:971-978. 
Melzack R, Stillwell DM, Fox EJ. Trigger points and acupuncture points for pain: Correlations and implications. Pain.1977;3:3-23.

Moskowitz RW, Davis W, Sanmarco J, Martens M, Baker J, Mayor M, Burnsstein AH, Frankel VH. experimentally induced degenerative joint lesions following partial meniscectomy in the rabit. Arthritis Rheum.1973;16(3):397-405.

Muir H. Molecular approach to the understanding of arthrosis. Ann Rheum Dis.1977;36: 199-2.

Naredo E, Cabero F, Palop MJ, Collado P, Cruz A, Crespo M. Ultrasonographic findings in knee osteoarthritis: a comparative study with clinical and radiographic assessment. Osteoarthritis Cartilage.2005;13(7):568-74.

National Institute for Health and Clinical Excellence (NICE). Osteoarthritis. The care and management of osteoarthritis in adults. NICE clinical guideline. 2008;59.

Noyes FR, Mooar LA, Barber SD. The assessment of work-related activities and limitations in knee disorders. Am J Sports Med.1991;19(2):178-88.

Osiri M, Welch V, Brosseau L, Shea B, McGowan J, Tugwell P, Wells G. Transcutaneous electrical nerve stimulation for knee osteoarthritis. Cochrane Database Syst Rev. 2000;(4):CD002823. 
Peyron JG. Epidemiologic and Etiologic approach of osteoarthritis. Sem Arthritis Rheum. 1979;8:288-306.

Philadelphia Panel evidence-based clinical practice guidelines on selected rehabilitation interventions for knee pain. Phys Ther.2001;81:1675-1700.

Pimenta CA de M, Teixeira MJ. Questionário de dor Mcgill: prosposta de adaptação para a língua portuguesa. Rev Esc Enf USP.1996;30(3):473-483.

Rebelatto JR, Morelli JGS. Fisioterapia Geriátrica - A Prática da Assistência ao Idoso. São Paulo:Manole;2007.

Robinson AJ, Snyder-Mackler L. Electrical stimulation for pain modulation. Clinical Electrotherapy and electrophysiologic testing. Baltimore: Williams \&Wilkins;1995:29192.

Santos CC, Pereira LSM, Resende MA, Magno F, Aguiar V. Aplicação da versão brasileira do questionário de dor Mcgill em idosos com dor crônica. Acta fisiatrica.2006;13(2):7582.

Schmidt RF, Willis WD. Encyclopedia of Pain.New York:Springer,2007 
Shanahan C, Ward AR, Robertson VJ. Comparison of the analgesic efficacy of interferential therapy and transcutaneous electrical nerve stimulation. Physiotherapy.2006; 92:247-253.

Sluka KA, Vance CGT, Lisi L. High-frequency, but not low-frequency, transcutaneous electrical nerve stimulation reduces aspartate and glutamate release in the spinal cord dorsal horn. J Neurochem.2005;95:1794-1801.

Sluka KA, Walsh D. Transcutaneous Electrical Nerve Stimulation: Basic Science Mechanisms and Clinical Effectiveness. The Journal of Pain.2003;4(3):109-121.

Sluka KA, Bailey K, Bogush J, Olson R, Ricketts A. treatment with either high or low frequency TENS reduces the secondary hyperalgesia observed after injection of kaolin and carrageenan into the knee joint. Pain.1998;77(1):97-102.

Smith CR, Lewith GT, Machin D. TNS and osteo-arthritic pain. Preliminary study to establish a controlled method of assessing transcutaneous nerve stimulation as a treatment for the pain caused by osteo-arthritis of the knee. Physiotherapy.1983;69(8):266-8.

Srikanth VK, Fryer JL, Zhai G, et al. A metaanalysis of sex differences prevalence, incidence and severity of osteoarthritis. Osteoarthritis cartilage.2005;13(9):769-81. 
Steultjens MP, Dekker J, van Baar ME, Oostendorp RA, Bijlsma JW. Range of joint motion and disability in patients with osteoarthritis of the knee or hip. Rheumatology (Oxford).2000;39(9):955-61.

Tegner Y, Lysholm J. Rating systems in the evaluation of knee ligament injuries. Clin Orthop Relat Res.1985;(198):43-9.

Vance CGT, Radhakrishnan R, Skyba DA, Sluka KA. Transcutaneous electrical nerve stimulation at both high and low frequencies reduces primary hyperalgesia in rats with joint inflammation in a time-dependent manner. Phys Ther.2007;87:44-51

Wang JQ, Mao L, Han JS. Comparison of the antinociceptive effects induced by electroacupuncture and transcutaneous electrical nerve stimulation in the rat. Int $J$ Neurosci.1992;65:117-29.

Woolf CJ, Mitchell D, Barrett GD: Antinociceptive effect of peripheral segmental electrical stimulation in the rat. Pain.1980;8:237-252.

Yamamura Y.Acupuntura tradicional: a arte de inserir.São Paulo:Roca; 2001. 